\title{
Variations in Overwintering Depth Distributions of Calanus finmarchicus in the Slope Waters of the NW Atlantic Continental Shelf and the Labrador Sea
}

\author{
Erica Head \\ Department of Fisheries and Oceans, Bedford Institute of Oceanography, \\ P.O. Box 1006, Dartmouth, NS, B2Y 4A2 \\ Email: HeadE@mar.dfo-mpo.gc.ca \\ and \\ Pierre Pepin \\ Department of Fisheries and Oceans, Northwest Atlantic Fisheries Centre, \\ P.O. Box 5667, St. John's, NL, A1C 5X1
}

Head, E., and P. Pepin. 2007. Variations in overwintering depth distributions of Calanus finmarchicus in the slope waters of the NW Atlantic continental shelf and the Labrador Sea. J. Northw. Atl. Fish. Sci., 39: 49-69. doi:10.2960/J.v39.m600

\begin{abstract}
Vertical depth distributions of Calanus finmarchicus were examined in autumn and winter (2001-2003) for the slope and offshore waters of the Canadian Atlantic continental shelf from the south Labrador Shelf in the north to the southwestern tip of the Scotian Shelf in the south as well as along sections across the Labrador Sea and in Cabot Strait. A total of 324 samples were collected at 53 stations that ranged over $\sim 19$ degrees of latitude and $\sim 17$ degrees of longitude.

Calanus finmarchicus populations in the subsurface layers (depths $>100$ or $200 \mathrm{~m}$ ) were dominated $(>90 \%)$ by CV copepodites off the western Scotian Shelf, in Cabot Strait, the central Newfoundland slope waters and the Labrador Sea. Along the slope between Flemish Pass and the eastern Scotian Shelf CVs made up $60-80 \%$ of the population in autumn and $80-86 \%$ in winter, with accompanying CIVs being replaced by CVs and adults between autumn and winter. CVs were deepest off the Greenland Shelf (70\% below $1000 \mathrm{~m}$ ) and shallowest in Cabot Strait (80\% in the 100-300 m interval; bottom depth $\sim 450 \mathrm{~m}$ ). Overwintering depth intervals were generally broad and covered large ranges of temperature and salinity.

There were relatively high concentrations $\left(>15 \mathrm{~m}^{-3}\right.$ ) of late stage (CIV-CVI) C. finmarchicus in the surface layers in the Cabot Strait region in autumn (2003) and in the slope waters off St. Pierre Bank (south Newfoundland Shelf) in winter (2003). These were probably the result of late seasonal production in the Gulf of St. Lawrence and Cabot Strait region, or on the Newfoundland Shelf where vertical ring net tows indicated high numbers $\left(>10000 \mathrm{~m}^{-2}\right)$ of $C$. finmarchicus at stations upstream of the St. Pierre Bank sampling area.

The vertical distribution data from winter 2003 suggest that transport of overwintering animals around the Tail of the Grand Bank where water depths are $>1000 \mathrm{~m}$ and southwestwards along the Scotian shelf break was limited, and that populations along the slope between the NW Grand Bank and the eastern Scotian Shelf had important local sources. There was also evidence of northeasterly transport of overwintering CVs from the western Scotian Shelf to the central Scotian Shelf slope waters between October and December 2003.
\end{abstract}

Keywords: Calanus, Labrador, NW Atlantic, overwinter, plankton, Scotia Shelf, vertical distribution.

\section{Introduction}

The copepod Calanus finmarchicus provides an important food source for larval groundfish and pelagic fish on the NW Atlantic continental shelf, where it can constitute $70 \%$ or more of the zooplankton biomass. The life cycle is annual over much of its range (Conover, 1988), which includes the North Atlantic waters north of the 
Gulf Stream from Georges Bank and the Gulf of Maine in the southwest to the Norwegian Sea and Barents Sea in the northeast. Calanus finmarchicus reproduces before and during the spring phytoplankton bloom (e.g. Norwegian Sea, Niehoff et al., 1999; Labrador Sea, Head et al., 2000; Scotian Shelf, McLaren et al., 2001) and the offspring develop in the surface layers in spring/summer. During summer and autumn, most of the new generation migrate downwards, mainly as stage CV pre-adult copepodites, to enter a period of dormancy, often referred to as diapause (e.g. Scotian Shelf, Sameoto and Herman, 1990; McLaren et al., 2001). On the Scotian Shelf some individuals do not descend, but mature to produce a second generation that contributes to the following year's adult spawning population (McLaren et al., 2001). Nevertheless, the seasonal descent of most of the population means that $C$. finmarchicus are largely absent from shelf regions in winter, which must be re-populated in spring from nearby deep waters. The deep waters adjacent to the NW Atlantic continental shelf to the east of the Tail of the Grand Bank comprise the southeasterly flowing western margin of the sub-polar NW Atlantic gyre (Loder et al., 1998, Fig. 1). The sub-polar gyre includes the Labrador and Irminger Seas and is bounded on its southern side by the North Atlantic Current. To the west of the Tail of the Bank the waters adjacent to the shelf comprise the westerly flowing northern boundary of a re-circulation gyre, henceforward referred to as the Slope Water gyre. The Slope Water gyre is bounded on its southern side by the north wall of the Gulf Stream, with easterly and westerly limits at the Tail of the Grand Bank and Cape Hatteras, respectively. Wiebe (2001) suggested that these gyres, together with the NE Atlantic Norwegian Sea gyre, form three distinct retention areas and distribution centres for C. finmarchicus overwintering in the N. Atlantic. Head et al. (2003) reported high concentrations of $C$. finmarchicus in the near surface waters of the Labrador Slope and central Labrador Sea (i.e. the sub-polar gyre) in spring, which included large numbers of overwintered CVs and females (Head et al., 2000), supporting the idea that the sub-polar gyre can provide a springtime source to the Labrador and Newfoundland Shelves. In addition, Head et al. (1999) reported high springtime levels of C. finmarchicus along the central and western Scotian shelf-break, consistent with the idea of a Slope Water gyre source for these regions of the Scotian Shelf.

From the Labrador Shelf to the Gulf of Maine, the NW Atlantic continental shelf is an advective system, with equatorward flow over the shelf and in the slope waters (Loder et al., 1998, Fig. 1). In spring and summer $C$. finmarchicus are advected southwards over the shelves in the surface layers, while in autumn and winter

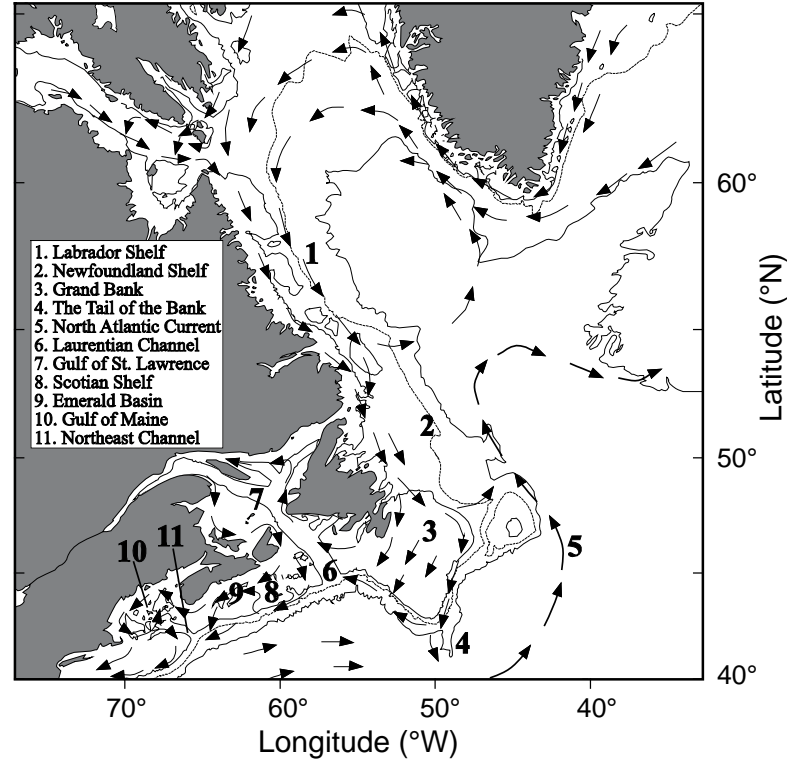

Fig. 1. Major currents of the NW Atlantic shelf and Labrador Sea region (re-drawn from Head and Sameoto, in press, after Loder et al., 1998).

southward transport of overwintering $C$. finmarchicus at depth can occur in the slope waters. Flow around the Tail of the Bank can connect the NW Atlantic sub-polar and Slope Water gyres, although generally much of the flow is deflected to the northeast to join the North Atlantic Current.

Zakardjian et al. (2003) developed a biophysical model that supports the idea that the Slope Water gyre may indeed retain overwintering $C$. finmarchicus exported from the Scotian Shelf and the Laurentian Channel, which can return to the shelf the following season. Speirs et al. (2006) developed a basin-scale biophysical model for $C$. finmarchicus for the entire North Atlantic, which suggests connectivity throughout the entire domain, although it predicts that advective transport has little effect on the population dynamics of $C$. finmarchicus within the NW Atlantic sub-polar and Norwegian Sea gyres. These models do, however, show that transport is important for shelf regions and at the limits of the geographic range of C. finmarchicus, and indicate that the population in the Gulf of St. Lawrence is self-sustaining.

Existing reports of overwintering depths of $C$. finmarchicus in the North Atlantic show that they vary from 300-1 $500 \mathrm{~m}$, with most populations west of Iceland occurring in waters of $\sim 4^{\circ} \mathrm{C}$, while most populations east of Iceland occur in waters between $-1-2^{\circ} \mathrm{C}$ (Halvorsen et al., 2003; Heath et al., 2004). Off Rockall Bank and in the Norwegian Trench, however, C. finmarchicus 
overwinter at $7-8^{\circ} \mathrm{C}$ (Heath et al., 2004) and overwintering temperatures of up to $11^{\circ} \mathrm{C}$ have been reported for Emerald Basin (on the Scotian Shelf) and west of the British Isles (Kaartvedt, 1996). Most overwintering C. finmarchicus occur at salinities of $\sim 34.9 \%$. Heath et al.'s (2004) summary of data from many contributors was rich in observations east of Greenland but provided only a brief summary of data from the Labrador Sea and there were no data from the Northwest Atlantic (Newfoundland to the southern Scotian Shelf).

In this paper we present detailed observations of hydrography and the vertical distribution of $C$. finmarchicus in autumn and/or winter in the Labrador Sea, the slope waters from the south Labrador Shelf in the north to the western tip of the Scotian Shelf in the south, the Slope Water gyre and the Cabot Strait region. No such observations have been reported before for these regions of the NW Atlantic, which cover 19 degrees of latitude and $\sim 17$ degrees of longitude. Our observations have enabled us to examine the winter-time connectivity of populations among regions, and the importance of different sources to different slope water regions. In addition, we present observations on the distribution of $C$. finmarchicus on the shelves in 2001 and 2003, which show that the species is not completely dormant in October-December.

\section{Materials and Methods}

Sampling was conducted either as part of regional oceanographic surveys coordinated by the Atlantic Zone Monitoring Program (AZMP; Therriault et al., 1998) or as part of directed studies, some of which have been ongoing for many years (e.g. Labrador Sea AR7W line). Samples from AZMP surveys were collected using a multiple net system at the deepest stations of the fixed transects. Other sampling sites, such as those to the West of the Southeast Shoals (SPB, GBL1 and GBL2 lines, Fig. 2), were chosen to provide observations for previously under-represented regions. Hydrographic, water and plankton sampling in the autumn was conducted at stations on the Newfoundland Shelf and in the slope waters east of the Tail of the Grand Bank and south of the Labrador Shelf between 15-24 November 2001 (Fig. 2, Tables 1 and 3). Similar sampling in autumn at stations west of the Tail of the Bank (west of the SEGB line), on the Scotian Shelf and in the slope waters, was between 19-31 October 2003. Winter cruises included sampling at stations along a section across the Labrador Sea between 3-9 December 2002 and at stations in the slope waters to the west of the Tail of the Grand Bank between 11-21 December 2003.

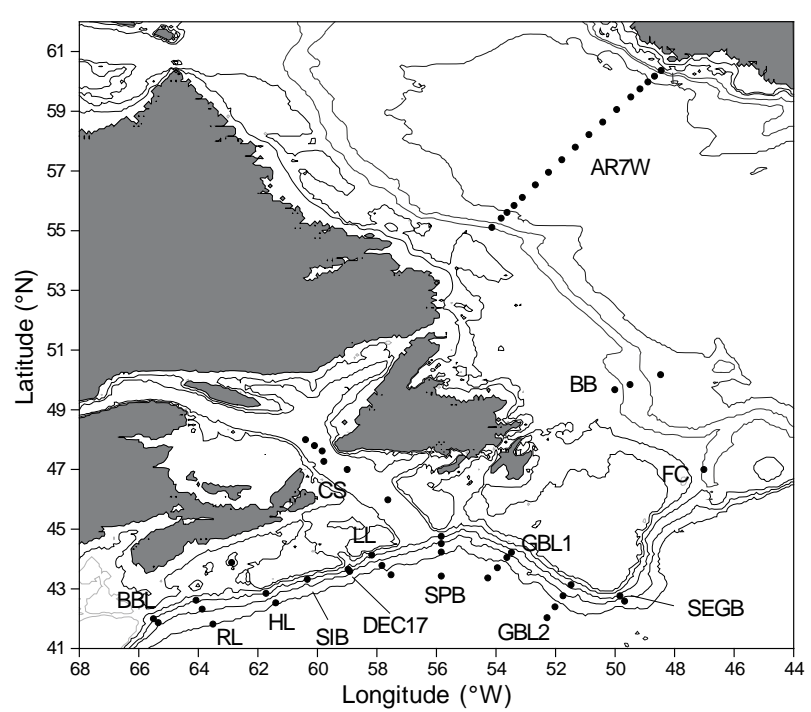

Fig. 2. Stations where vertically stratified Multi-net tows were performed. The lines are from northeast to southwest: AR7W, Atlantic Repeat Section 7 West (of the WOCE programme); BB, Bonavista Bay Line; FC, Flemish Cap Line; SEGB, Southeast Grand Bank Line; GBL2, Grand Bank Line 2; GBL1, Grand Bank Line 1; SPB, St Pierre Bank; CS, Cabot Strait region (includes all stations in the Laurentian Channel); LL, Louisbourg Line; DEC17, stations occupied on December 17; SIB, Sable Island Bank; HL, Halifax Line; RL, Roseway Line; BBL, Browns Bank Line. The lines denote 100, 200, 1 000, 2000 and $3000 \mathrm{~m}$ contours.

\section{Hydrographic measurements and water sampling}

Temperature and salinity profiles were collected at all sampling stations using a Seabird Model SBE 25 sensor on cruises in autumn 2003 and winter 2002 and 2003 or a SBE911 sensor in autumn of 2001, mounted on a CTD rosette. Water samples were collected in the $0-100 \mathrm{~m}$ depth interval at eight fixed depths $(5,10,20$, $30,40,5075,100 \mathrm{~m})$ in autumn 2001 and at nine fixed depths $(0,10,20,30,40,50,60,80,100 \mathrm{~m})$ in autumn 2003 and winter 2002. Water samples $(100 \mathrm{ml})$ were filtered on to Whatman GF/F glass fibre filters and chlorophyll concentrations were measured after $\sim 24 \mathrm{~h}$ extraction in $90 \%$ acetone at $-20^{\circ} \mathrm{C}$ using a Turner designs fluorometer and the Holm-Hansen et al. (1965) method, except in the case of the autumn 2001 cruise, when the Welshmeyer (1994) method was used.

\section{Zooplankton sampling}

Vertically stratified tows were made using a $0.5 \times 0.5 \mathrm{~m}$ square-mouthed Hydro-bios Multi-net sampler in water depths of $>400 \mathrm{~m}$ (Fig. 2, Table 1). The 
TABLE 1. Stations where vertically stratified net tow were made using the Multi-net in autumn (A) and winter (W) 2001, 2002 and 2003. Stations are listed with lines in order from the north east to the southwest, and stations seaward from Canada. Stations not identifiable in the Fig. 2 figure legend are in the Cabot Strait region: LH1-3, Laurentian Hole Stations 1-3 (numbered proceeding up the Laurentian Channel); CSL4, Cabot Strait Line Station 4; LCN, Laurentian Channel North (a little south of Cabot Strait); LCL4, Laurentian Channel Line Station 4 (mid-way between Cabot Strait and the shelf-break).

\begin{tabular}{|c|c|c|c|c|c|c|c|}
\hline \multirow[b]{2}{*}{ Station name } & Latitude & Longitude & \multirow{2}{*}{$\begin{array}{l}\text { Nominal } \\
\text { depth }\end{array}$} & \multirow{2}{*}{$\begin{array}{c}\text { Sample } \\
\text { season/year (m) }\end{array}$} & \multirow{2}{*}{$\begin{array}{l}\text { Maximum tow depth } \\
\qquad(\mathrm{m})\end{array}$} & \multirow{2}{*}{$\begin{array}{l}\text { Surface tow } \\
\text { depth }\end{array}$} & \multirow[b]{2}{*}{ No. of nets } \\
\hline & \multicolumn{2}{|c|}{ (Decimal Degrees) } & & & & & \\
\hline AR7W-08 & 55.12 & 54.13 & 960 & W, 2002 & 840 & $0-200$ & 5 \\
\hline AR7W-10 & 55.42 & 53.82 & 2700 & W, 2002 & 1500 & $0-200$ & 7 \\
\hline AR7W-11 & 55.61 & 53.63 & 2900 & W, 2002 & 1000 & $0-200$ & 5 \\
\hline AR7W-12 & 55.85 & 53.40 & 3160 & W, 2002 & 1000 & $0-200$ & 5 \\
\hline AR7W-13 & 56.11 & 53.12 & 3340 & W, 2002 & 2000 & $0-200$ & 9 \\
\hline AR7W-14 & 56.55 & 52.68 & 3500 & W, 2002 & 1000 & $0-200$ & 5 \\
\hline AR7W-16 & 57.37 & 51.80 & 3560 & W, 2002 & 2000 & $0-200$ & 9 \\
\hline AR7W-18 & 58.22 & 50.88 & 3570 & W, 2002 & 1000 & $0-200$ & 5 \\
\hline AR7W-19 & 58.63 & 50.42 & 3540 & W, 2002 & 2000 & $0-200$ & 9 \\
\hline AR7W-20 & 59.07 & 49.95 & 3490 & W, 2002 & 1000 & $0-200$ & 5 \\
\hline AR7W-21 & 59.48 & 49.47 & 3410 & W, 2002 & 2000 & $0-200$ & 9 \\
\hline AR7W-22 & 59.75 & 49.17 & 3270 & W, 2002 & 1000 & $0-200$ & 5 \\
\hline AR7W-23 & 59.99 & 48.90 & 3040 & W, 2002 & 1000 & $0-200$ & 5 \\
\hline AR7W-24 & 60.18 & 48.68 & 2880 & W, 2002 & 2000 & $0-200$ & 9 \\
\hline AR7W-26 & 60.37 & 48.50 & 2740 & W, 2002 & 540 & $0-100$ & 5 \\
\hline BB-11 & 49.67 & 50.01 & 607 & A, 2001 & 580 & $0-100$ & 5 \\
\hline BB-12 & 49.85 & 49.50 & 1372 & A, 2001 & 1300 & $0-200$ & 5 \\
\hline BB-14 & 50.18 & 48.47 & 2349 & A, 2001 & 2000 & $0-200$ & 9 \\
\hline FC-17 & 47.00 & 47.02 & 1130 & A, 2001 & 1130 & $0-200$ & 5 \\
\hline SEGB-16 & 42.77 & 49.84 & 1485 & A, 2001 & 1480 & $0-200$ & 5 \\
\hline SEGB-17 & 42.59 & 49.68 & 2500 & A, 2001 & 2200 & $0-300$ & 5 \\
\hline GBL2-3 & 43.14 & 51.48 & 1000 & W, 2003 & 900 & $0-200$ & 5 \\
\hline GBL2-4 & 42.77 & 51.75 & 2270 & W, 2003 & 2000 & $0-200$ & 9 \\
\hline GBL2-5 & 42.40 & 52.02 & 3400 & W, 2003 & 1000 & $0-200$ & 5 \\
\hline GBL2-6 & 42.03 & 52.29 & 4300 & W, 2003 & 1000 & $0-200$ & 5 \\
\hline GBL1-3.5 & 44.22 & 53.48 & 1300 & W, 2003 & 1250 & $0-200$ & 5 \\
\hline GBL1-4 & 44.05 & 53.64 & 2380 & W, 2003 & 2000 & $0-200$ & 9 \\
\hline GBL1-5 & 43.71 & 53.95 & 3786 & W, 2003 & 1000 & $0-200$ & 5 \\
\hline GBL1-6 & 43.37 & 54.28 & 4206 & W, 2003 & 1000 & $0-200$ & 5 \\
\hline SPB08 & 44.76 & 55.84 & 1072 & W, 2003 & 1030 & $0-200$ & 5 \\
\hline SPB09 & 44.52 & 55.84 & 2260 & A, 2003 & 1000 & $0-200$ & 5 \\
\hline SPB10 & 44.23 & 55.84 & 2923 & $\mathrm{~A}+\mathrm{W}, 2003$ & 1000 & $0-200$ & 5 \\
\hline SPB12 & 43.43 & 55.84 & 3057 & W, 2003 & 1000 & $0-200$ & 5 \\
\hline LH3 & 48.00 & 60.40 & 486 & A, 2003 & 478 & $0-100$ & 5 \\
\hline LH2 & 47.80 & 60.10 & 508 & A, 2003 & 508 & $0-100$ & 5 \\
\hline LH1 & 47.62 & 59.84 & 534 & A, 2003 & 524 & $0-100$ & 5 \\
\hline CSL4 & 47.27 & 59.78 & 473 & A, 2003 & 454 & $0-100$ & 5 \\
\hline $\mathrm{LCN}$ & 47.00 & 59.00 & 449 & A, 2003 & 435 & $0-100$ & 5 \\
\hline LCL4 & 45.98 & 57.63 & 490 & A, 2003 & 481 & $0-100$ & 5 \\
\hline LL7 & 44.13 & 58.18 & 960 & A, 2003 & 925 & 0-200 & 5 \\
\hline LL8 & 43.78 & 57.83 & $>2500$ & A, 2003 & 1000 & $0-200$ & 5 \\
\hline LL9 & 43.47 & 57.43 & $>3500$ & A, 2003 & 1000 & $0-200$ & 5 \\
\hline DEC17-1 & 43.65 & 58.97 & 1390 & W, 2003 & 1200 & $0-200$ & 5 \\
\hline DEC17-2 & 43.59 & 58.92 & 1890 & W, 2003 & 1800 & $0-200$ & 5 \\
\hline SIB6 & 43.32 & 60.34 & 1400 & A, 2003 & 1000 & $0-200$ & 5 \\
\hline HL3 & 43.88 & 62.88 & 276 & W, 2003 & 270 & $0-50$ & 3 \\
\hline HL6 & 42.85 & 61.73 & 1056 & W, 2003 & 1030 & $0-200$ & 5 \\
\hline HL7 & 42.53 & 61.40 & 2750 & $\mathrm{~A}+\mathrm{W}, 2003$ & 1000 & $0-200$ & 5 \\
\hline RL5 & 42.62 & 64.08 & 900 & $\mathrm{~A}+\mathrm{W}, 2003$ & $850(\mathrm{~A}), 930(\mathrm{~W})$ & $0-200$ & $5(\mathrm{~A}), 5(\mathrm{~W})$ \\
\hline RL6 & 42.32 & 63.87 & 1880 & $\mathrm{~A}+\mathrm{W}, 2003$ & $1000(\mathrm{~A}), 1875(\mathrm{~W})$ & $0-200$ & $5(\mathrm{~A}), 9(\mathrm{~W})$ \\
\hline RL7 & 41.82 & 63.51 & 3050 & A, 2003 & 1000 & $0-200$ & 5 \\
\hline BBL6 & 42.00 & 65.51 & 1000 & $\mathrm{~A}+\mathrm{W}, 2003$ & 946(A), 43(W) & $0-200$ & $5(\mathrm{~A}), 5(\mathrm{~W})$ \\
\hline BBL7 & 41.35 & 65.35 & 1850 & $\mathrm{~A}+\mathrm{W}, 2003$ & 1000 & $0-200$ & 5 \\
\hline
\end{tabular}


TABLE 2. Stations where ring net tows were made in autumn (A) and winter (W) 2001, 2002 and 2003. Stations are listed with lines in order from the north east to the southwest, and stations seaward from Canada. Samples were collected between the bottom and the surface, or $1000 \mathrm{~m}$ and the surface at stations deeper than $1000 \mathrm{~m}$. Stations not identifiable in the Fig. 2 figure legend are stations 1-5 of the Cabot Strait region: CSL1-5, across Cabot Strait, numbered from Nova Scotia to Newfoundland.

\begin{tabular}{|c|c|c|c|c|c|c|c|c|c|}
\hline \multirow{2}{*}{$\begin{array}{l}\text { Station } \\
\text { name }\end{array}$} & Latitude & Longitude & \multirow{2}{*}{$\begin{array}{l}\text { Nominal } \\
\text { depth } \\
\text { (m) }\end{array}$} & \multirow[t]{2}{*}{$\begin{array}{c}\text { Sample } \\
\text { season/year }\end{array}$} & \multirow{2}{*}{$\begin{array}{l}\text { Station } \\
\text { name }\end{array}$} & Latitude & Longitude & \multirow{2}{*}{$\begin{array}{l}\text { Nominal } \\
\text { depth } \\
\text { (m) }\end{array}$} & \multirow[t]{2}{*}{$\begin{array}{c}\text { Sample } \\
\text { season/year }\end{array}$} \\
\hline & \multicolumn{2}{|c|}{ (Decimal Degrees) } & & & & \multicolumn{2}{|c|}{ (Decimal Degrees) } & & \\
\hline BB-01 & 48.73 & 52.97 & 98 & A, 2001 & SEGB-10 & 44.36 & 51.10 & 73 & A, 2001 \\
\hline BB-03 & 48.83 & 52.65 & 256 & A, 2001 & SEGB-11 & 44.00 & 50.81 & 73 & A, 2001 \\
\hline BB-04 & 48.92 & 52.40 & 352 & A, 2001 & SEGB-12 & 43.63 & 50.52 & 66 & A, 2001 \\
\hline BB-05 & 49.03 & 52.07 & 290 & A, 2001 & SEGB-13 & 43.20 & 50.17 & 67 & A, 2001 \\
\hline BB-06 & 49.10 & 51.83 & 298 & A, 2001 & SEGB-15 & 42.85 & 49.89 & 389 & A, 2001 \\
\hline BB-07 & 49.19 & 51.54 & 312 & A, 2001 & SEGB-16 & 42.77 & 49.84 & 1485 & A, 2001 \\
\hline BB-08 & 49.28 & 51.28 & 323 & A, 2001 & SEGB-17 & 42.59 & 49.68 & 2500 & A, 2001 \\
\hline BB-09 & 49.37 & 51.02 & 340 & A, 2001 & SEGB-19 & 42.08 & 49.27 & 3000 & A, 2001 \\
\hline BB-10 & 49.52 & 50.53 & 332 & A, 2001 & GBL2-1 & 43.50 & 51.20 & 76 & W, 2003 \\
\hline BB-11 & 49.67 & 50.01 & 607 & A, 2001 & GBL2-2 & 43.31 & 51.34 & 130 & W, 2003 \\
\hline BB-12 & 49.85 & 49.50 & 1372 & A, 2001 & GBL1-1 & 44.56 & 53.16 & 101 & W, 2003 \\
\hline BB-13 & 50.00 & 49.00 & 1866 & A, 2001 & GBL1-2.5 & 44.47 & 53.24 & 125 & W, 2003 \\
\hline BB-14 & 50.18 & 48.47 & 2349 & A, 2001 & SPB5A & 45.05 & 55.95 & 73 & W, 2003 \\
\hline BB-15 & 50.33 & 47.95 & 2624 & A, 2001 & SPB6 & 44.93 & 55.84 & 154 & W, 2003 \\
\hline FC-01 & 47.00 & 52.83 & 107 & A, 2001 & CSL1 & 46.96 & 60.22 & 77 & A, 2003 \\
\hline FC-02 & 47.00 & 52.71 & 188 & A, 2001 & CSL2 & 47.02 & 60.12 & 180 & A, 2003 \\
\hline FC-03 & 47.00 & 52.58 & 159 & A, 2001 & CSL3 & 47.10 & 59.99 & 330 & A, 2003 \\
\hline FC-04 & 47.00 & 52.32 & 126 & A, 2001 & CSL4 & 47.27 & 59.78 & 473 & A, 2003 \\
\hline FC-05 & 47.00 & 52.03 & 140 & A, 2001 & CSL5 & 47.43 & 59.56 & 475 & A, 2003 \\
\hline FC-06 & 47.00 & 51.49 & 101 & A, 2001 & CSL6 & 47.58 & 59.34 & 265 & A, 2003 \\
\hline FC-07 & 47.00 & 51.00 & 106 & A, 2001 & LL1 & 45.83 & 59.85 & 90 & A, 2003 \\
\hline FC-09 & 47.00 & 50.00 & 85 & A, 2001 & LL2 & 45.66 & 59.70 & 130 & A, 2003 \\
\hline FC-10 & 47.00 & 49.12 & 82 & A, 2001 & LL3 & 45.49 & 59.52 & 130 & A, 2003 \\
\hline FC-12 & 47.00 & 48.12 & 136 & A, 2001 & LL4 & 45.16 & 59.18 & 102 & A, 2003 \\
\hline $\begin{array}{l}\text { FC-14 } \\
\text { FC-15 }\end{array}$ & $\begin{array}{l}47.00 \\
47.00\end{array}$ & $\begin{array}{l}4 / .50 \\
47.25\end{array}$ & $\begin{array}{l}218 \\
535\end{array}$ & A, 2001 & LL5 & 44.82 & 58.85 & 215 & A, 2003 \\
\hline FC-17 & 47.00 & 47.02 & 1130 & A, 2001 & LL6 & 44.48 & 58.51 & 66 & A, 2003 \\
\hline FC-18 & 47.00 & 46.83 & 1172 & A, 2001 & LL7 & 44.13 & 58.18 & 960 & A, 2003 \\
\hline FC-20 & 47.00 & 46.48 & 350 & A, 2001 & LL8 & 43.78 & 57.83 & $>2500$ & A, 2003 \\
\hline FC-21 & 47.00 & 46.02 & 304 & A, 2001 & HL1 & 44.40 & 63.45 & 85 & A, 2003 \\
\hline FC-24 & 47.00 & 45.21 & 170 & A, 2001 & HL2 & 44.27 & 63.32 & 150 & A, 2003 \\
\hline FC-26 & 47.00 & 44.77 & 150 & A, 2001 & HL3 & 43.88 & 62.88 & 270 & A, 2003 \\
\hline FC-29 & 47.00 & 44.23 & 276 & A, 2001 & HL4 & 43.48 & 62.45 & 81 & A, 2003 \\
\hline FC-31 & 47.00 & 43.83 & 557 & A, 2001 & HL5 & 43.18 & 62.10 & 95 & A, 2003 \\
\hline FC-33 & 47.00 & 43.40 & 1236 & A, 2001 & HL6 & 42.85 & 61.73 & 1056 & A, 2003 \\
\hline FC-35 & 47.00 & 43.00 & 3550 & A, 2001 & HL7 & 42.53 & 61.40 & 2750 & A, 2003 \\
\hline SEGB-01 & 46.58 & 52.93 & 53 & A, 2001 & BBL1 & 43.25 & 65.48 & 70 & A, 2003 \\
\hline SEGB-03 & 46.35 & 52.73 & 173 & A, 2001 & BBL2 & 43.00 & 65.48 & 115 & A, 2003 \\
\hline SEGB-05 & 46.07 & 52.50 & 92 & A, 2001 & BBL3 & 42.76 & 65.48 & 100 & A, 2003 \\
\hline SEGB-06 & 45.79 & 52.27 & 85 & A, 2001 & BBL4 & 42.45 & 65.48 & 100 & A, 2003 \\
\hline SEGB-07 & 45.46 & 52.00 & 82 & A, 2001 & BBL5 & 42.13 & 65.48 & 200 & A, 2003 \\
\hline SEGB-08 & 45.10 & 51.70 & 73 & A, 2001 & BBL6 & 42.00 & 65.48 & 1000 & A, 2003 \\
\hline SEGB-09 & 44.73 & 51.40 & 71 & A, 2001 & BBL7 & 41.87 & 65.35 & 1850 & A, 2003 \\
\hline
\end{tabular}

Multi-net was deployed vertically and collected samples from up to five depth intervals while being towed upwards. At some stations of $>1000 \mathrm{~m}$ depth two separate hauls were performed and up to nine depth intervals were sampled. At a station in Emerald Basin (HL3) only three depth intervals were sampled in a water depth of $270 \mathrm{~m}$ (Table 1$)$. The volume of water sampled $\left(\mathrm{m}^{3}\right)$ over each depth interval was estimated as $0.25 \mathrm{~m}^{2} \times$ the towed depth (m). On the continental shelves, zooplankton samples were also collected in vertical ring net hauls between the bottom and the surface, or $1000 \mathrm{~m}$ and the surface for depths $>1000 \mathrm{~m}$, with the net rigged in such a way that it towed only on the way up (Table 2). Data from these samples were used to provide a perspective of the abundance of $C$. finmarchicus on and off the continental shelves during the overwintering period. The volume of 
TABLE 3. Water column abundances of Calanus finmarchicus (individuals $\mathrm{m}^{-2}$ ) in the Multi-net tows summed over all the depth intervals sampled. At stations in the Labrador Sea, denoted with an asterisk, due to the poor condition of some samples, it was not possible to differentiate CI, CII and CIII C. finmarchicus stages; instead the sum of CI-CIII is shown in the column for CII. Stations not identifiable in the Fig. 2 figure legend are in the Cabot Strait region: LH1-3, Laurentian Hole Stations 1-3 (numbered proceeding up the Laurentian Channel); CSL4, Cabot Strait Line Station 4; LCN, Laurentian Channel North (a little south of Cabot Strait); LCL4, Laurentain Channel Line Station 4 (mid-way between Cabot Strait and the shelf-break).

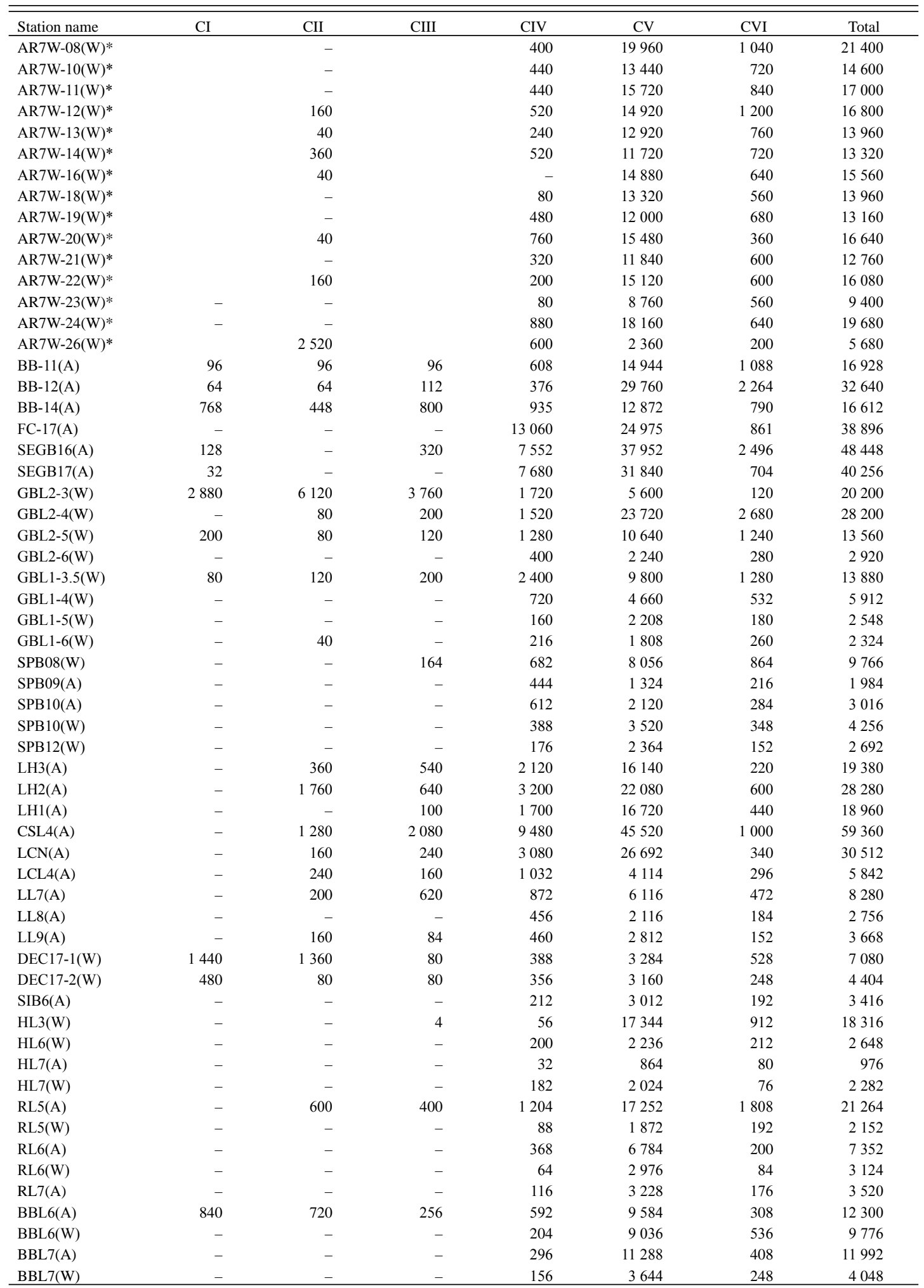


water sampled $\left(\mathrm{m}^{3}\right)$ was assumed to be the cross-sectional area of the mouth of the net $\left(\mathrm{m}^{2}\right) \times$ the towed depth $(\mathrm{m})$. Both net systems were fitted with $200 \mu \mathrm{m}$ mesh nets and retrieved at $\sim 1 \mathrm{~m} \mathrm{~s}^{-1}$. Zooplankton samples were preserved in $5 \%$ buffered formalin for subsequent identification and enumeration.

\section{Results}

Areal distributions in autumn (2001, 2003) and winter (2002, 2003) in Multi-net tows

Calanus finmarchicus populations below the surface sampling layer were assumed to be in an overwintering state. At most stations, the surface sampling layer was 0-200 m, but off the Tail of the Grand Bank (SEGB-17) it was $0-300 \mathrm{~m}$, in the Cabot Strait region and at some shallow stations it was 0-100 m, and in Emerald Basin it was 0-50 m (Table 1). Calanus finmarchicus in slope waters consisted mainly of stage CV copepodites (Fig. 3) although $12-34 \%$ of animals were CIV copepodites between Flemish Pass (FC-17) and the Eastern Scotian Slope (ESS) in autumn. In winter the CIV contribution dropped to $<10 \%$ in these areas. Less than $10 \%$ of animals were adults in both autumn and winter.

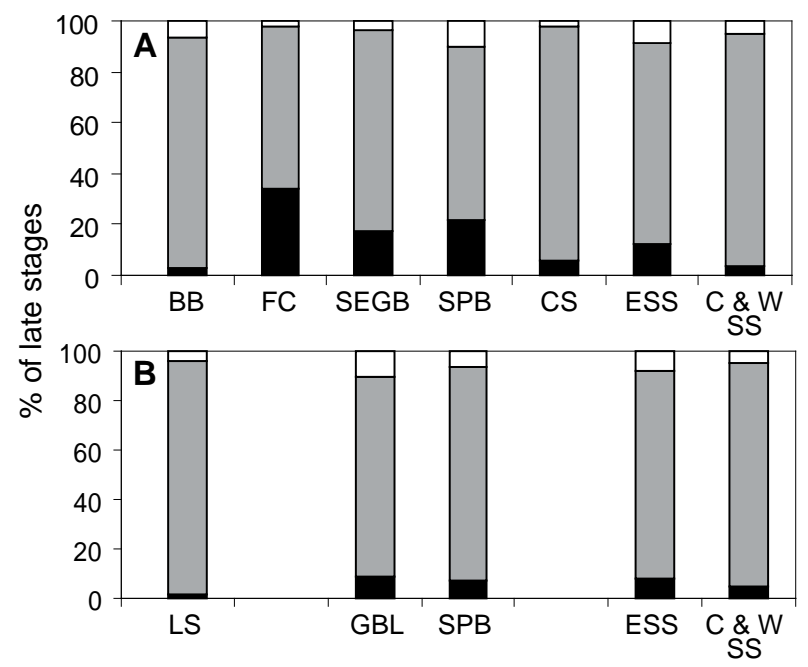

Fig. 3. Relative stage composition (\%) of CIV (black), CV (grey) and adult (white) C. finmarchicus in the subsurface layers of the NW Atlantic slope waters and Labrador Sea in Multi-net tows in (A) autumn and (B) winter. Results are averaged over stations in different regions: BB, Bonavista Bay Line; FC, Flemish Cap Line; SEGB, South East Grand Bank Line; SPB, St Pierre Bank Line; CS, Cabot Strait region; ESS, Eastern Scotian Slope (east of and including DEC17); C\&W SS, Central and Western Scotian Slope Water (west of and including SIB); LS, Labrador Sea; GBL, Grand Bank Lines (GBL1 and GBL2).
In autumn, the areal concentrations (number $\mathrm{m}^{-2}$ ) of late stage $C$. finmarchicus (CIV-CVI) in the subsurface layers (depths $>100$ or $200 \mathrm{~m}$ ) were highest at stations in the Cabot Strait region (CSR) and east of the Tail of the Grand Bank (Fig. 4, Table 3). There were moderate concentrations off the Western Scotian Shelf (WSS), and lower concentrations off St. Pierre Bank (SPB) and the ESS. Concentrations of late stages in the surface layers were high only in the CSR. In winter, subsurface concentrations of late stages were highest in the Labrador Sea, on the GBL2 line and in Emerald Basin (Fig. 5, Table 3). Surface layer concentrations were highest on the Western Grand Bank lines (GBL1 and GBL2) and near SPB. Young (CI-CIII) stage C. finmarchicus copepodites were abundant in the surface layers in the CSR in autumn and on GBL2 in winter (Fig. 6, Table 3).

Relationship between CV distributions and hydrographic properties ( $T$ and $S$ ) in autumn $(2001,2003)$ and winter $(2002,2003)$

Subsurface temperature and salinity ranges varied little to the east of the Tail of the Grand Bank and temperature varied more than salinity in the slope waters farther west. In the CSR there were large changes in both temperature and salinity with depth. High concentrations of CV C. finmarchicus $\left(\mathrm{m}^{-3}\right)$ occurred over a wide range of temperatures and salinities throughout the
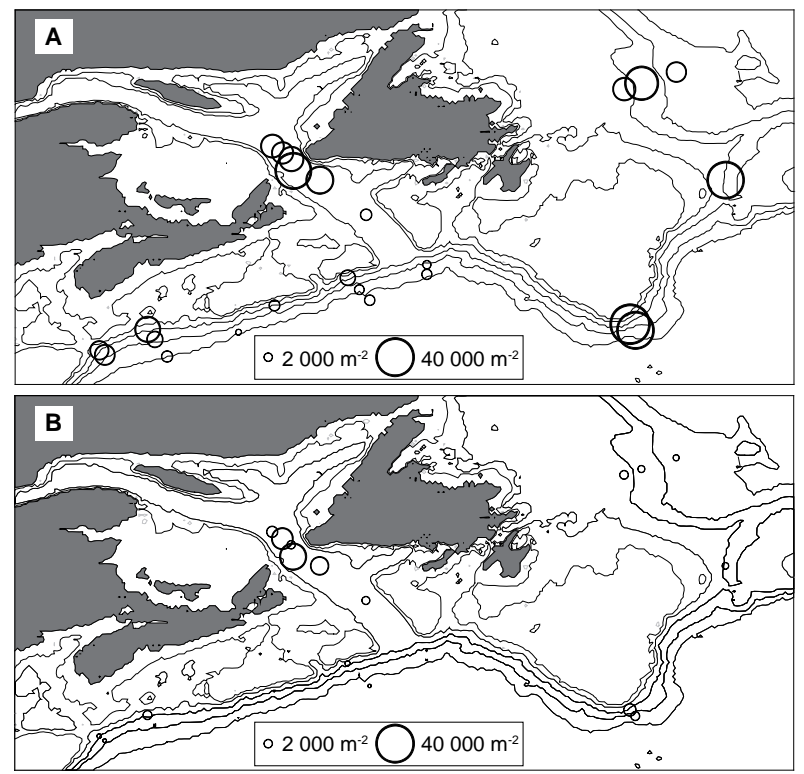

Fig. 4. Areal concentrations of stage CIV-CVI C. finmarchicus in autumn 2001 (East of the Tail of the Grand Bank) or 2003 (West of the Tail of the Bank) in the (A) sub-surface ( $>100$ or $200 \mathrm{~m}$ ) layers to the bottom or $1000 \mathrm{~m}$ and (B) surface ( $<100$ or $200 \mathrm{~m}$ ) layers. 


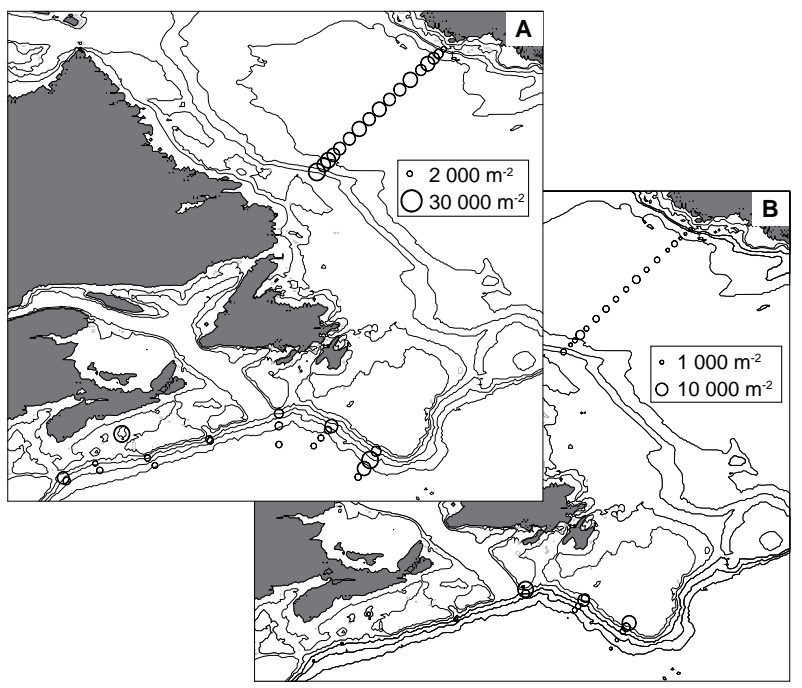

Fig. 5. Areal concentrations of stage CIV-CVI C. finmarchicus in winter 2002 (Labrador Sea) or 2003 (West of the Tail of the Grand Bank) in the sub-surface layers ( $>200 \mathrm{~m}$ or $>50 \mathrm{~m}$ in Emerald Basin, mid-Scotian Shelf) to (A) the bottom or $1000 \mathrm{~m}$ and surface layers (B) $<200 \mathrm{~m}$ or $<50$ in Emerald Basin. Note that the surface layer data also includes stations sampled by ring net from bottom to surface for the SPB, GBL1 and GBL2 lines.

entire sampling area (Fig. 7). The highest concentrations were in waters of low $\left(<2^{\circ} \mathrm{C},<33.5 \mathrm{PSU}\right)$ and intermediate $\left(\sim 5^{\circ} \mathrm{C}, \sim 35 \mathrm{PSU}\right)$ average temperature and salinity in the CSR, and in Emerald Basin, where the average temperature and salinity were both high $\left(>9^{\circ} \mathrm{C},>35 \mathrm{PSU}\right)$.

\section{Vertical distributions of CV C.finmarchicus}

The Labrador Sea section (winter 2002). The highest concentrations of CVs on the AR7W section across the Labrador Sea in winter 2002 were in the Labrador Slope waters (AR7W-08) at depths >600 m (Fig. 8). In the western Labrador Sea CV concentrations peaked in the 200-400 m depth interval, with few individuals below $1000 \mathrm{~m}$. Farther east, larger proportions of CVs were at greater depths, and near the Greenland Shelf (AR7W-24) $70 \%$ of the CVs were below $1000 \mathrm{~m}$. At station AR7W26 the Multi-net tow was to $<600 \mathrm{~m}$ and CVs were much less abundant than elsewhere. Water temperatures below $200 \mathrm{~m}$ were $\sim 4^{\circ} \mathrm{C}$ and uniform with depth in the west (AR7W-08 to AR7W-16) but increased at depths <400 $\mathrm{m}$ in the east (AR7W-21, AR7W-24). Salinities below $200 \mathrm{~m}$ were relatively uniform. In western and central regions there were appreciable numbers of CVs in the nearsurface layer (0-200 m). Integrated abundances of CVs, omitting AR7W-26, ranged from a low of $\sim 900 \mathrm{~m}^{-2}$ at station AR7W-23 to a high of $\sim 20000 \mathrm{~m}^{-2}$ at AR7W-08

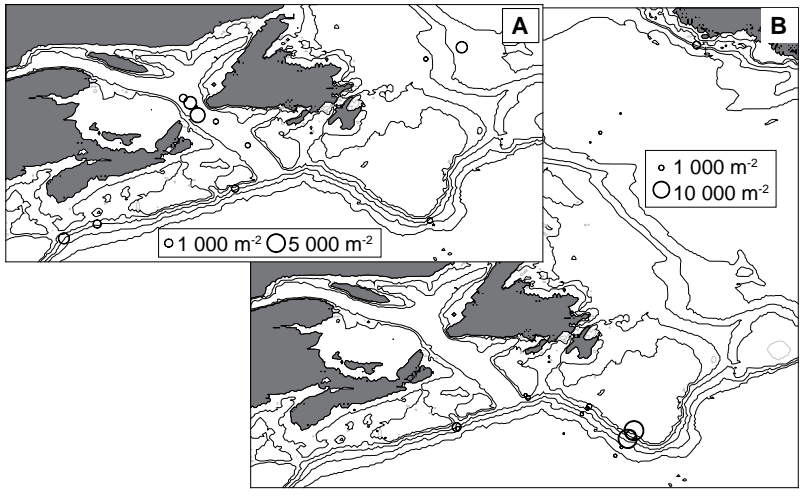

Fig. 6. Areal concentrations of stage CI-CIII C. finmarchicus in the surface layers ( $<100$ or $200 \mathrm{~m}$ ) in (A) autumn 2001 (East of the Tail of the Grand Bank) or 2003 (West of the Tail of the Bank), and (B) winter 2002 (Labrador Sea) or 2003 (West of the Tail of the Bank). Note that the surface layer data also includes stations sampled by ring net from bottom to surface for the SPB, GBL1 and GBL2 lines.

(Table 3). At AR7W-23 (not shown in Fig. 8) the Multinet tow was only to $1000 \mathrm{~m}$, however. If the vertical distribution of CVs had been the same at AR7W-24, then the total number here would have been higher by a factor of $\sim 3$. The average concentration of CVs over all stations (Tables 1 and 2), omitting AR7W-26, was $14000 \mathrm{~m}^{-2}$.

The Newfoundland Shelf, Flemish Pass and Tail of the Grand Bank, autumn 2001. For the three stations across the Newfoundland Slope on the Bonavista Bay line $(\mathrm{BB})$ the vertical distribution patterns were somewhat similar to those seen farther north on the western end of the AR7W section, in that the CV C. finmarchicus were deeper at the stations nearer the shelf (BB-11 and BB-12) than at the offshore station (BB-14), where the peak abundance was at 200-400 m (Fig. 9). On the other hand, the abundance peak at BB-12 was shallower than at AR7W-08. Farther south in Flemish Pass (FC-17) and at SEGB-16 the CVs were somewhat deeper than at BB-11 and BB-12, but farther offshore at SEGB-17 there was a relatively large number of $\mathrm{CV} C$. finmarchicus at 300-600 m, similar to the pattern at BB-14. Total water column concentrations of CVs at stations of $\sim 1000 \mathrm{~m}$ depth (BB-12, FC-17, SEB-16; 25 000-37 $000 \mathrm{~m}^{-2}$, Table 3) and at SEGB-17 (depth $2500 \mathrm{~m}, 31000 \mathrm{~m}^{-2}$ ) were amongst the highest seen in the study.

Temperature and salinity profiles below $\sim 300 \mathrm{~m}$ were relatively uniform (Figs. 7 and 9). Near surface layers were warmer and fresher with a thermocline/halocline within the top $200 \mathrm{~m}$ for stations on the Newfoundland Shelf and in Flemish Pass (FC-17). At SEGB-16 and 17, 


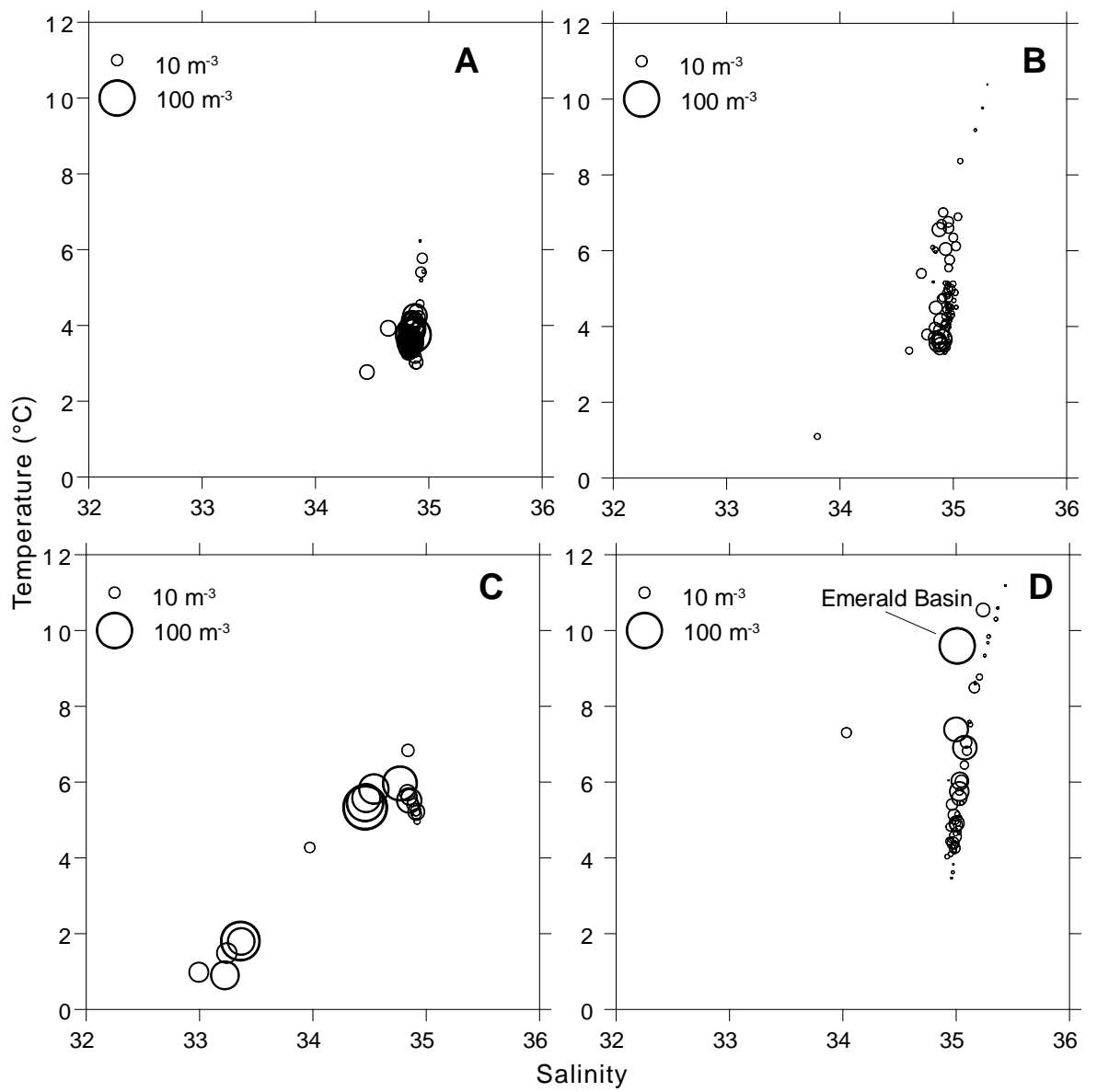

Fig. 7. Concentrations of $\mathrm{CV}$ C. finmarchicus $\left(\mathrm{m}^{-3}\right)$ in relation to temperature and salinity averaged over the capture depth intervals for different regions in autumn and winter: (A) East of the Tail of the Grand Bank (LS to SEGB), (B) Eastern slope waters (GBL2 to DEC-17), (C) Cabot Strait Region and (D) Central and Western Scotian Slope waters (SIB to BBL).

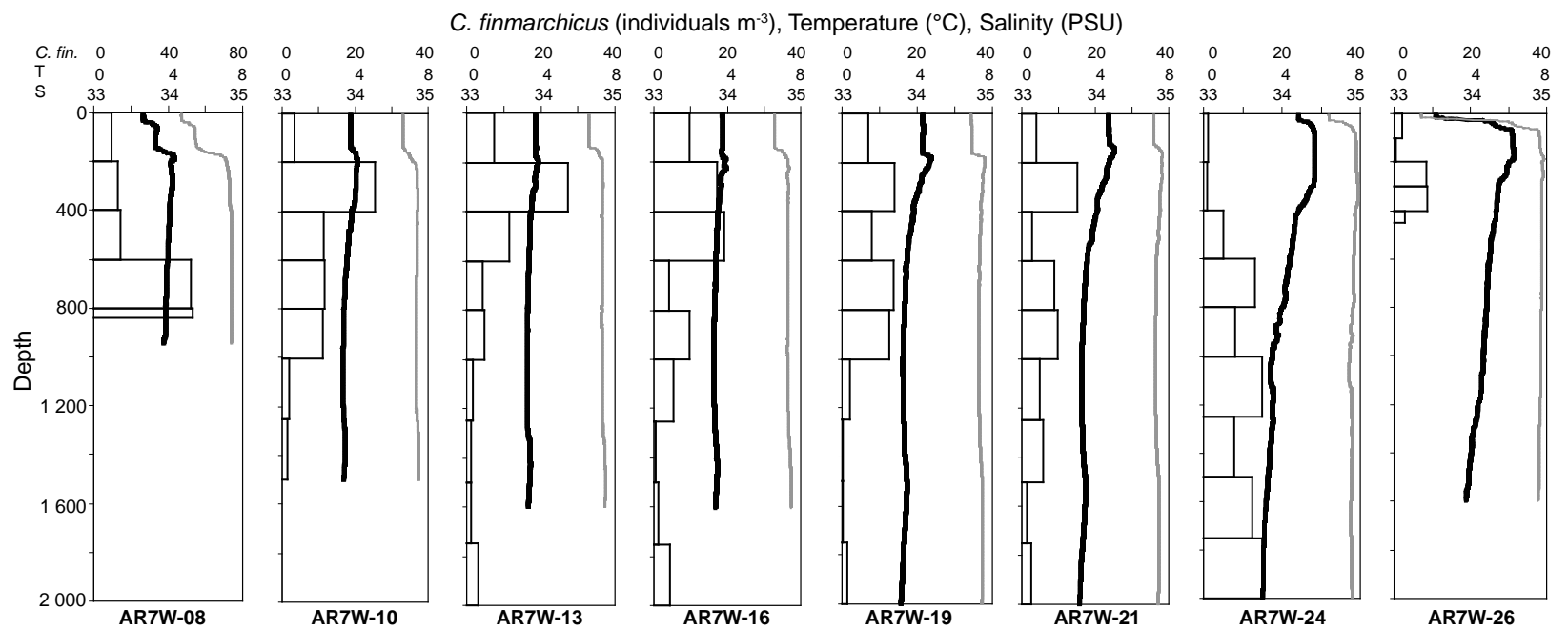

Fig.8. Vertical distribution of CV C. finmarchicus (individuals $\left.\mathrm{m}^{-3}\right)$, temperature $\left({ }^{\circ} \mathrm{C}\right.$, black line) and salinity (PSU, grey line) at selected stations of the AR7W line across the Labrador Sea in winter 2002. 

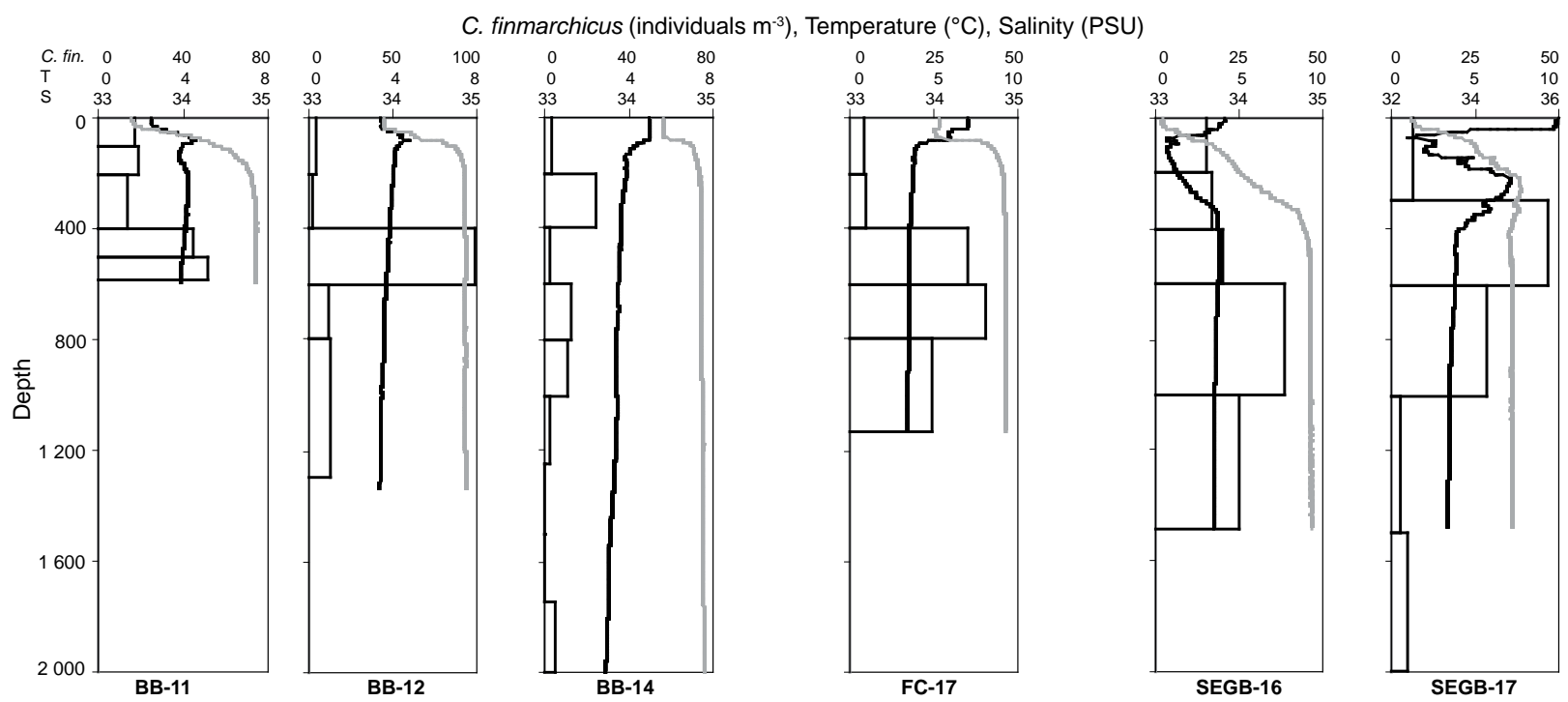

Fig.9. Vertical distribution of CV C. finmarchicus (individuals $\mathrm{m}^{-3}$ ), temperature $\left({ }^{\circ} \mathrm{C}\right.$, black line) and salinity (PSU, grey line) at stations on the Bonavista Bay (BB), Flemish Cap (FC) and Southeast Grand Bank (SEGB) Lines in November 2001.

there was evidence of a cold intermediate layer between 100 and $300 \mathrm{~m}(100-200 \mathrm{~m}$ at SEGB-17), but surface temperatures were higher at SEGB-17 due to the proximity of the western boundary of the Gulf Stream.

Slope waters west of the Tail of the Grand Bank (winter 2003). In winter 2003, on the most easterly line sampled (GBL2), CVs were most concentrated at depths close to $1000 \mathrm{~m}$, although the vertical distributions were broad and there were some CVs in the surface layer (Fig. 10). At GBL2-4 CVs were abundant below $1000 \mathrm{~m}$, but this was the only station west of the Tail of the Grand Bank where this was observed. At GBL1 peak abundances were shallower than at GBL2, with CVs broadly distributed from the surface to $1000 \mathrm{~m}$ at GBL1-3.5 and mostly above $400 \mathrm{~m}$ at GBL1-4. At both GBL1-3.5 and GBL1-4 there were appreciable numbers of CVs in the surface layer. At the SPB line there was a distinct difference between vertical distributions at the 1000 and the $\sim 3000 \mathrm{~m}$ contours. At SPB08 CVs were most concentrated at the surface, whereas at SPB10 the peak was at 400-600 m (Fig. 10). At the DEC17 stations, peak abundance was at 200-400 m, and there were appreciable numbers in the surface layer at DEC17-1. At stations of the Roseway and Halifax lines (RL and HL) peak abundance was at 400-600 m, and vertical distributions were narrower than farther east with few CVs in the surface layers. At BBL6 CVs showed a broad distribution peak between 400 and $800 \mathrm{~m}$, while at BBL7 the peak concentration was at $200-400 \mathrm{~m}$. Total water column concentrations were highest at GBL2-4 (24 000 $\mathrm{m}^{-2}$ ) and otherwise generally higher (average $5500 \mathrm{~m}^{-2}$ ) to the east of the Laurentian Channel than to the west (average $2500 \mathrm{~m}^{-2}$ ), with the exception of BBL6 (9 000 $\mathrm{m}^{-2}$ ) (Table 3).

Temperature and salinity profiles at GBL2-3 showed a cool fresh layer at much the same depth interval (50$300 \mathrm{~m}$ ) as was observed at SEGB-16. At all of the stations from the GBL2 line to the ESS there were cool subsurface layers, with salinities fresher above this layer than beneath. The subsurface layer was coolest and deepest at SPB08 (reaching $-0.9^{\circ} \mathrm{C}$ at $100 \mathrm{~m}$ ). Farther west there were no cool subsurface layers and temperatures and salinities were lowest near the surface, below which there were warm, salty layers between $\sim 100$ and $500 \mathrm{~m}$.

Slope waters between St. Pierre Bank and Browns Bank (autumn 2003). Peak abundance of CV C. finmarchicus was at $400-600 \mathrm{~m}$ at most stations at both the 1000 and $2000 \mathrm{~m}$ isobaths between SPB and Browns Bank (Fig. 11), which is north of the BBL stations shown in Fig. 2. One exception was at the $1000 \mathrm{~m}$ contour off the ESS (LL7), where the peak was at $200-400 \mathrm{~m}$. A second was at the $1000 \mathrm{~m}$ contour on the Roseway Line (RL), although here the peak abundance was over a range (300-500 m) that overlapped the 400-600 m interval sampled elsewhere. Total water column concentrations were highest off the WSS (BBL and RL) ranging between $\sim 7000 \mathrm{~m}^{-2}$ (RL6) and $\sim 17000 \mathrm{~m}^{-2}$ (RL5) (Table $3)$. Farther east total water column concentrations were higher at the $1000 \mathrm{~m}$ contour $\left(\geq 3000 \mathrm{~m}^{-2}\right)$ than farther offshore $\left(\leq 2000 \mathrm{~m}^{-2}\right)$. 

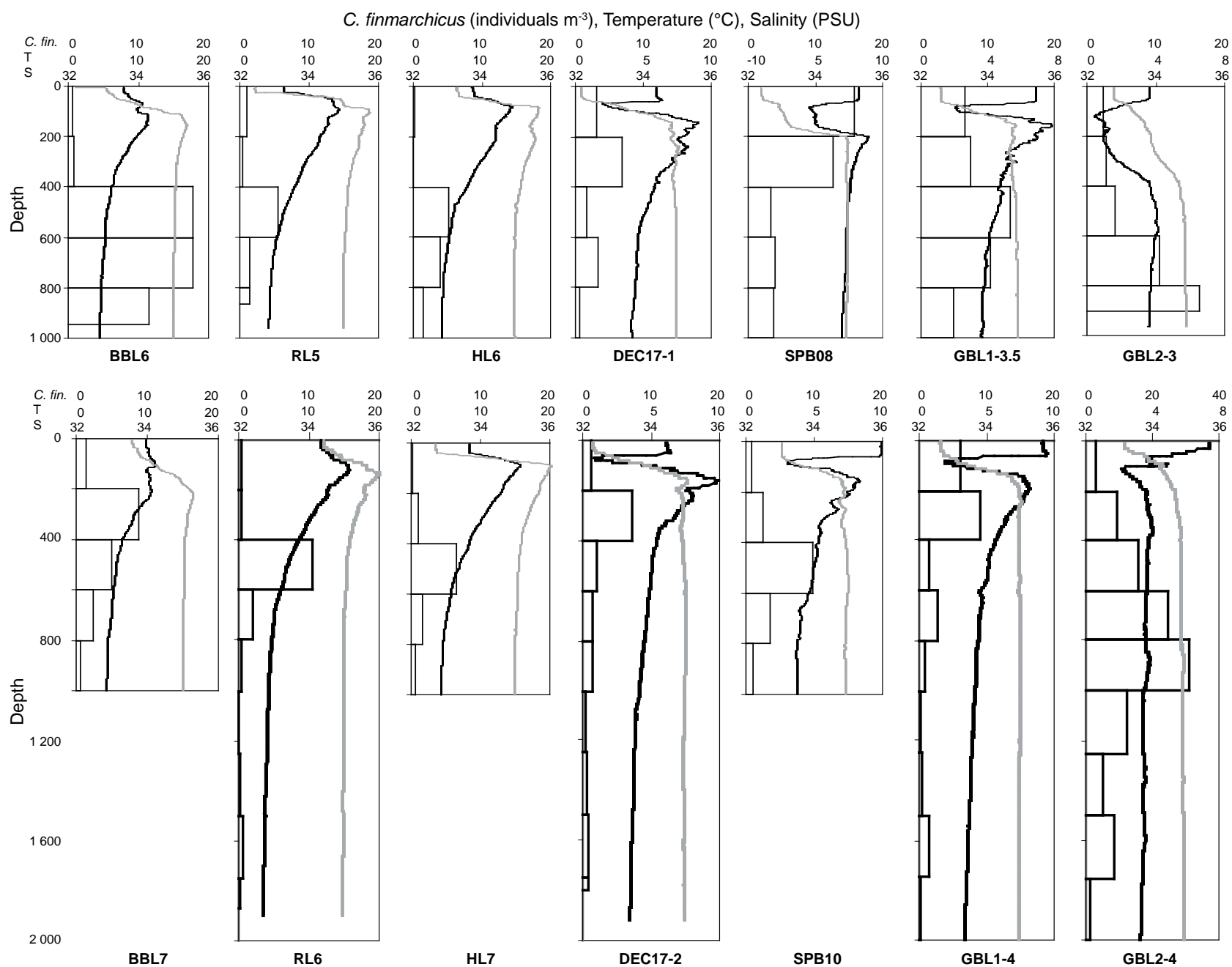

Fig.10. Vertical distribution of CV C. finmarchicus (individuals $\left.\mathrm{m}^{-3}\right)$, temperature $\left({ }^{\circ} \mathrm{C}\right.$, black line) and salinity (PSU, grey line) at stations along off the western (BBL, RL), central (HL) and eastern (DEC17) Scotian Shelf and off St. Pierre Bank (SPB) and the SW Grand Bank (GBL1 and GBL2) in December 2003. The upper panels correspond to the $1000 \mathrm{~m}$ isobath and the lower panels to the $\sim 2000 \mathrm{~m}$ isobath, except for SPB10, where the depth was $\sim 2900 \mathrm{~m}$.

Temperatures were generally maximal at the surface and at all stations, except HL7, there was a cool subsurface layer (generally $50-100 \mathrm{~m}$ ), beneath which was a warm layer extending to $\sim 600 \mathrm{~m}$. Salinities were minimal at the surface and maximal in the subsurface warm layer. At HL7 the maximum temperature and minimum salinity were at the surface, with a gradual decline below the mixed layer $(50 \mathrm{~m})$ and slight interleaving of warmer and cooler layers between 50 and $100 \mathrm{~m}$.

Cabot Strait region and off the Western Scotian Shelf, autumn 2003 and Emerald Basin and off the south Newfoundland Shelf and Western Grand Bank (winter 2003). In the CSR, concentrations of CV C. finmarchicus generally peaked at depths of 200-300 m, and at some stations there were large numbers at shallower depths (Fig. 12). The highest total water column concentration (46 $000 \mathrm{~m}^{-2}$ ) was at CSL4 and the lowest $\left(4000 \mathrm{~m}^{-2}\right)$ at LCL4 (Table 3). Temperature and salinity profiles from CSL4 into the Gulf of St Lawrence were similar. The surface water was warm and fresh; there was an underlying cool fresh layer (50-200 m) and warmer saltier water from $200 \mathrm{~m}$ to the bottom. The patterns at LCN and LCL4 were similar to the others, but were distinguished by having water of $<0^{\circ} \mathrm{C}$ in their subsurface cool layers and at LCN the surface water was especially fresh (salinity <32 PSU). The concentration of CV C. finmarchicus in Emerald Basin was highest in the deepest layer (100-260 m), coincident with the highest temperatures and salinities (Figs. 7 and 12).

Concentrations of CV C. finmarchicus peaked at $400-600 \mathrm{~m}$ at most stations beyond the $2000 \mathrm{~m}$ isobath (Fig. 12). At LL9, however, the peak was at 200-400 m, 

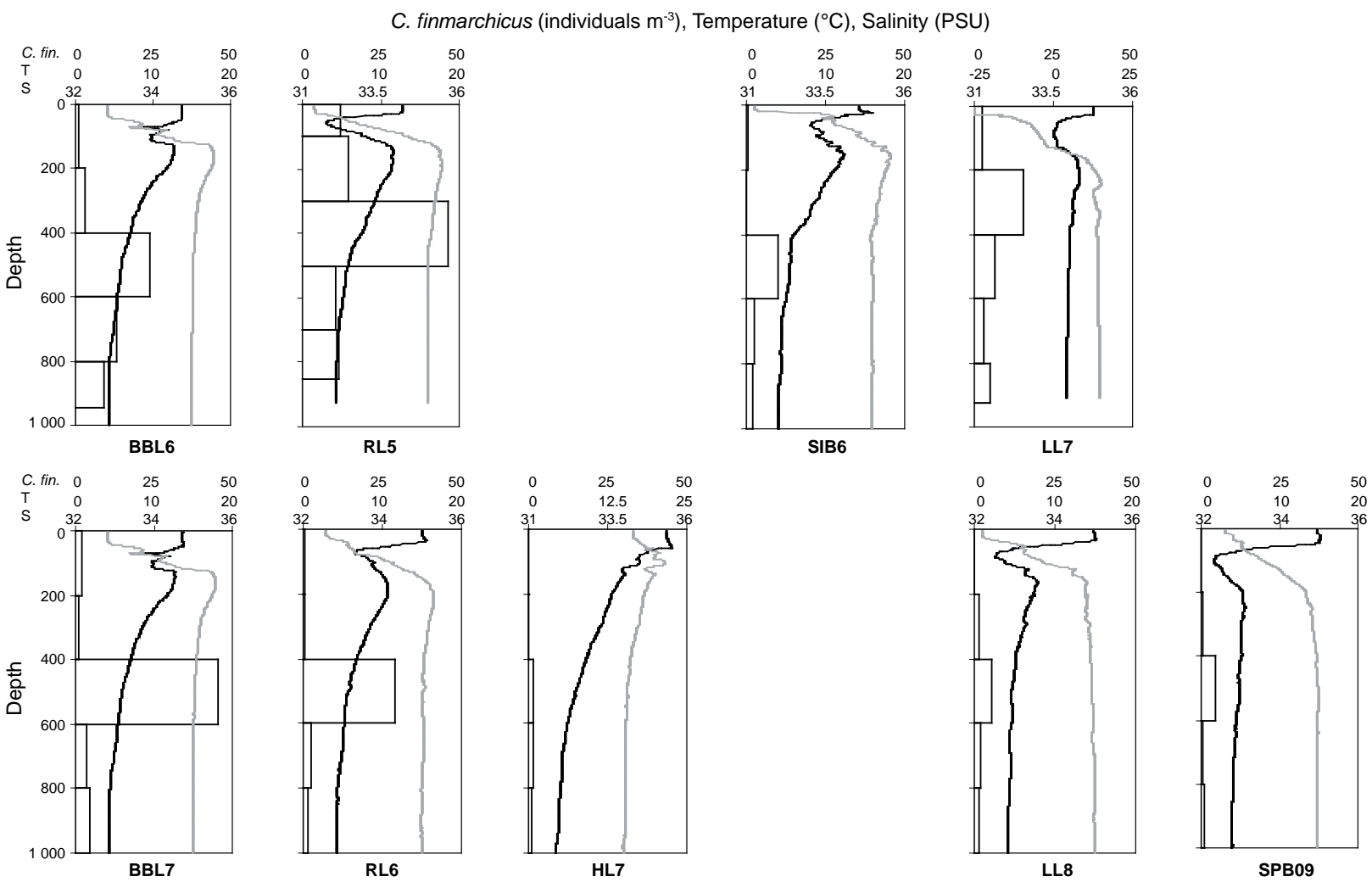

Fig.11. Vertical distribution of CV C. finmarchicus (individuals $\left.\mathrm{m}^{-3}\right)$, temperature $\left({ }^{\circ} \mathrm{C}\right.$, black line) and salinity (PSU, grey line) at stations off the western (BBL and RL) central (HL) and eastern (SIB, LL) Scotian Shelf and off St. Pierre Bank (SPB) in October 2003. The upper panels correspond to the $\sim 1000 \mathrm{~m}$ isobath and the lower panels to the $\sim 2000 \mathrm{~m}$ isobath.

while at GBL2-5 CVs were equally abundant from 400$1000 \mathrm{~m}$. For the latter station it is likely that the population extended below $1000 \mathrm{~m}$, as it did at GBL2-4, so that the total water column abundance was underestimated. Even so, the total concentration was much higher at GBL2-4 than at the other offshore stations to the west of the Tail of the Grand Bank (11 $000 \mathrm{~m}^{-2}$ versus an average of $\left.2400 \mathrm{~m}^{-2}\right)$.

All stations showed a surface mixed layer of relatively freshwater overlying warmer (GBL1-6, GBL2-5, GBL2-6) or cooler (LL-9, SPB12, GBL1-5) layers. Surface temperatures were highest in the west (RL7) and lower at stations closer to the shelf-break for a given line (e.g. GBL1-5 versus GBL1-6 and GBL2-5 versus GBL2-6). Maximum concentrations of CVs were generally associated with water that was relatively cool and relatively salty.

Ring net stations on the Newfoundland and Scotian Shelves and in the Cabot Strait region. During the autumn 2001 cruise to the Newfoundland Shelf and Grand Bank and the autumn 2003 cruise to the Scotian
Shelf and Cabot Strait, ring net tows were made as part of the Atlantic Zone Monitoring Programme (AZMP, Therriault et al., 1998). Off Newfoundland, abundances of late stage (CIV-CVI) C. finmarchicus at a station inshore and to the north of the Grand Bank on the Flemish Cap Line (FC-06) and at another on Flemish Cap (FC-31) were $>100000 \mathrm{~m}^{-2}$, the highest seen anywhere in this study, while at most stations deeper than $90 \mathrm{~m}$ on the Newfoundland Shelf abundances were $>10000 \mathrm{~m}^{-2}$ (Fig. 13, Tables 3 and 4). On the Scotian Shelf, late stages were abundant $\left(>10000 \mathrm{~m}^{-2}\right)$ on the Halifax Line between Emerald Basin and Halifax and at most stations of the Browns Bank Line. In Cabot Strait, late stages were very abundant $\left(>25000 \mathrm{~m}^{-2}\right)$ at every station, except at the relatively shallow CSL1. Young stages (CI-CIII) of $C$. finmarchicus were generally less abundant than late stages in all regions (Fig. 13, Table 4). The maximum abundance of young stages on the Newfoundland Shelf was $6000 \mathrm{~m}^{-2}$ at FC-06, and while there were several stations with concentrations of $1000-4000 \mathrm{~m}^{-2}$, there were also several with effectively no young stages. On the Scotian Shelf and in Cabot Strait, concentrations of young stages were $1000-4000 \mathrm{~m}^{-2}$ or 


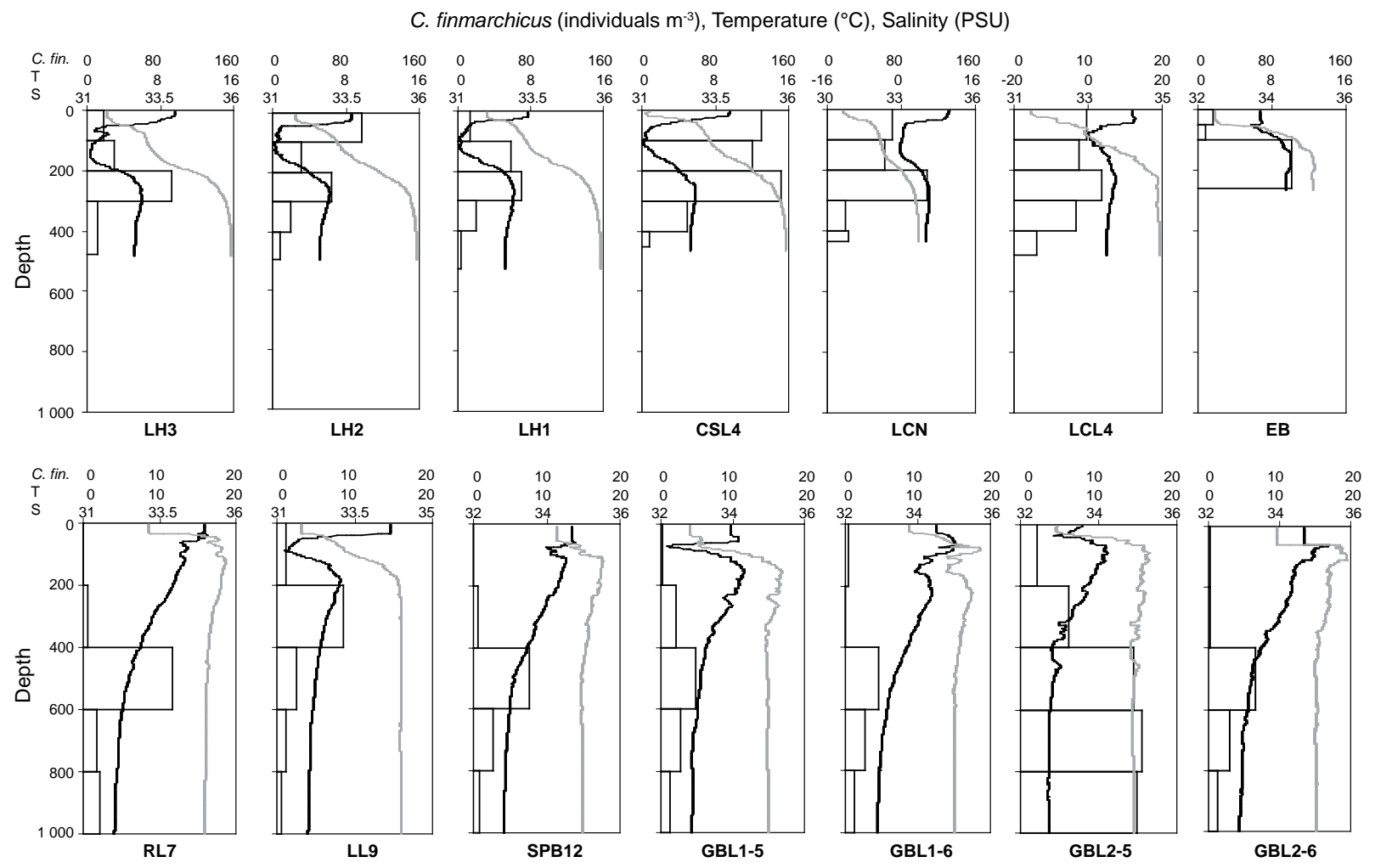

Fig.12. Vertical distribution of CV C. finmarchicus (individuals $\left.\mathrm{m}^{-3}\right)$, temperature $\left({ }^{\circ} \mathrm{C}\right.$, black line) and salinity (PSU, grey line) at stations in the Cabot Strait Region (LH3, LH2, LH1, CSL4, LCN, LCL4) in autumn 2003 and in Emerald Basin (EB) in winter 2003 (upper panel) and beyond the $2000 \mathrm{~m}$ contour off the western (RL7) and eastern (LL9) Scotian Shelf in autumn 2003 and the south Newfoundland Shelf (SPB) and western Grand Bank (GBL1 and GBL2) in winter 2003 (lower panel).

less, except at BBL4 and BBL3, where they were much higher (108 000 and $7000 \mathrm{~m}^{-2}$, respectively). In winter 2003, ring net tows were made at two stations near the shelf-break on each of the SPB, GBL1 and GBL2 lines. Abundances of late stage $C$. finmarchicus for these stations were 5 000-17 $000 \mathrm{~m}^{-2}$ (Fig. 5, Table 4), except at SPB5A where there were only $\sim 400 \mathrm{~m}^{-2}$. Young stage C. finmarchicus were abundant at the ring net stations of the GBL2 line, but not elsewhere (Fig. 6, Table 4).

\section{Discussion}

In this study we have shown substantial variations in autumn/winter vertical depth distributions of $C$. finmarchicus over a large geographic area of the Northwest Atlantic. The mean depth distribution of $C$. finmarchicus was shallowest in Emerald Basin (100-270 m), in Cabot Strait (100-300 m) and off the Eastern Scotian Shelf (200-400 m), while animals were generally found deepest in waters off the Western Scotian Shelf (400-950 m), Eastern and Southern Newfoundland (400-1500 m) and west of Greenland (600-2 $000 \mathrm{~m})$. There was consider- able variability in the mean depth of $C$. finmarchicus in the Labrador Sea, with animals generally being found at greater depths near the continental shelves than in the central basin.

\section{Interpreting spatial patterns of $\boldsymbol{C}$. finmarchicus areal abundance}

In autumn, late stage $C$. finmarchicus were most abundant in the subsurface layers at stations in the slope waters east of the Tail of the Grand Bank, off the WSS and in the CSR (Fig. 4, Table 3). These high concentrations probably reflected production in the regions from which these individuals originated, which the circulation indicates would be the Newfoundland Shelf, the Scotian Shelf and the Gulf of St. Lawrence, respectively (Fig. 1). In winter, subsurface late stage abundances were high at all stations of the AR7W transect across the Labrador Sea, in the slope waters of the GBL2 line and in Emerald Basin (Fig. 5, Table 2). For the Labrador Sea, the abundance of $C$. finmarchicus probably reflected production within the region, although the slope waters may be the areas of highest production with subsequent trans- 


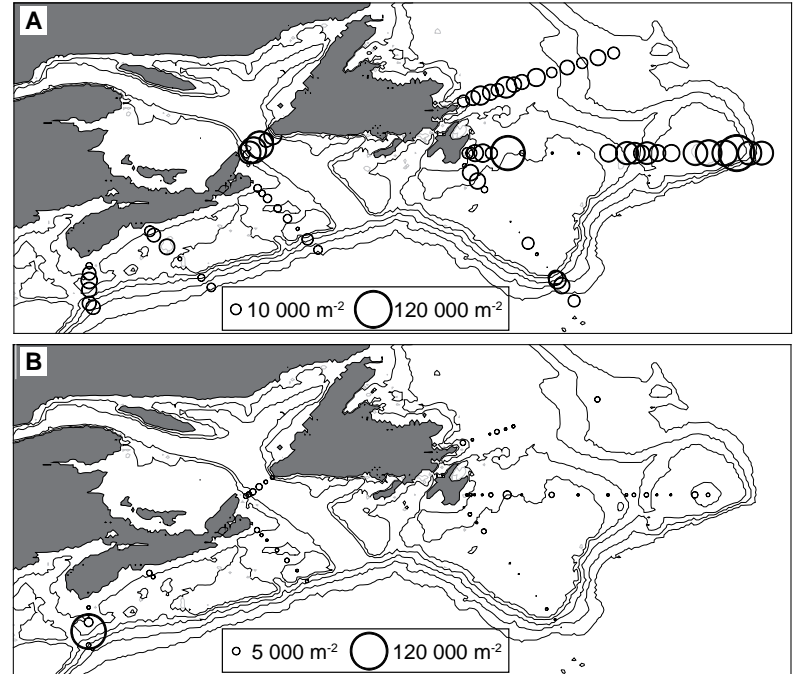

Fig.13. Areal concentrations of (A) stage CIV-CVI and (B) CI-CIII. C. finmarchicus determined by ring net tows from the bottom to the surface on the Bonavista Bay (BB), Flemish Cap (FC) and Southeast Grand Bank (SEGB) Lines in autumn (November) 2001 and on the Cabot Strait (CS), Louisbourg (LL), Halifax (HL) and Browns Bank (BBL) Lines in autumn (October) 2003.

port to the central Labrador Sea (Head et al., 2000), and there could have been input to eastern regions from the Irminger Sea. For the southwest Grand Bank (GBL2) the high levels probably resulted from advection around the Tail of the Grand Bank (cf. Figs. 9 and 10). For Emerald Basin, the levels likely reflected the production of the ESS, including advective input from the CSR and Gulf of St. Lawrence.

Abundances of C. finmarchicus overwintering in the Labrador Sea (9 000-20 $000 \mathrm{~m}^{-2}$ ) were similar to those reported for the Irminger Basin (7 000-30 $000 \mathrm{~m}^{-2}$; Gislason and Astthorsson 2000) and for the northern Norwegian Sea (4 000-37 $000 \mathrm{~m}^{-2}$; Dale et al., 1999). They were lower, however, than those reported for the FaroeShetland Channel (35 000-50 $000 \mathrm{~m}^{-2}$; Heath et al., 2000) and for some retentive areas southwest of Tromsøflaket off northern Norway (up to $150000 \mathrm{~m}^{-2}$; Halvorsen et al., 2003). The abundances of $C$. finmarchicus in the slope waters of the WSS (Table 3, RL and BBL, 4 000$21000 \mathrm{~m}^{-2}$ ) were similar to those reported by Miller et al. (1991) for the slope waters downstream off Georges Bank (5 000-10 $000 \mathrm{~m}^{-2}$ ). The high concentrations in the central Labrador Sea are consistent with the idea that this area is a distribution centre for $C$. finmarchicus for the NW Atlantic (sensu Wiebe, 2001). By contrast, the low concentrations $\left(<4000 \mathrm{~m}^{-2}\right)$ of late stage $C$. finmarchicus beyond the $2000 \mathrm{~m}$ isobath west of the Tail of the Grand
Bank (Fig. 12, Table 3) do not support the idea (Wiebe, 2001) that the central Slope Water gyre is an important overwintering area.

Late stage (CIV-VI) C. finmarchicus were abundant in the surface layers in the CSR in Multi-net tows, and there were also $>1000 \mathrm{~m}^{-2}$ young stages (CI-III) at CSL4 and LH2, and in the ring net tows (bottom to surface tows) at all Cabot Strait Line stations. Plourde and Runge (1993) measured egg production rates for $C$. finmarchicus in the Lower St. Lawrence Estuary between June and August and found relatively high rates in late August when their sampling ended. Thus, the seasonal cycle of production may not have finished by October 2003 in the CSR. In October 2003 chlorophyll concentrations were $>1 \mathrm{mg} \mathrm{m}^{-3}$ near the surface at all stations in the CSR, which should have been sufficient for phytoplankton alone to fuel egg production and growth and development of copepodites at in situ surface temperatures $\left(\sim 8^{\circ} \mathrm{C}\right.$; Campbell et al., 2001).

Young stage (CI-III) C. finmarchicus were found at levels of $>1000 \mathrm{~m}^{-2}$ at a number of stations throughout the region (Figs. 6 and 13, Tables 2 and 4) in autumn (12 stations on the Newfoundland Shelf, seven stations in CSR, eight stations on the Scotian Shelf, one off the ESS and two off the WSS) and winter (one station in the Labrador Sea, three near the SEGB and one off the ESS). Maximum chlorophyll concentrations were $>1 \mathrm{mg} \mathrm{m}^{-3}$ in autumn at five stations on the Newfoundland Shelf, at four CSR stations, at seven Scotian Shelf stations, and at the two stations off the WSS, and in winter at the station off the ESS in and at the SEGB stations . Although young stages were very abundant $\left(>100000 \mathrm{~m}^{-2}\right)$ at BBL4 in autumn, chlorophyll concentrations were not especially high there (maximum $1.25 \mathrm{mg} \mathrm{m}^{-3}$ ). The young stage copepodites that we observed would have derived from eggs laid 2-3 weeks previously. Thus, our observations of chlorophyll concentrations in situ do not allow us to determine whether there is some threshold of phytoplankton concentration needed to induce reproduction and the development through the naupliar stages, although it is likely that this is the case.

Our results suggest that in parts of our study area the production cycles for $C$. finmarchicus may extend later in the year than is seen elsewhere. In fact, at Stn. 27 $\left(46^{\circ} 33^{\prime} \mathrm{N} 52^{\circ} 35^{\prime} \mathrm{W}\right)$, a station on the inner Newfoundland Shelf that is sampled monthly as part of the AZMP programme (Therriault et al., 1998), appreciable concentrations $\left(>5000 \mathrm{~m}^{-2}\right)$ of young stage (CI-III) C. finmarchicus have been seen at least once in every month of the year except March and April over seven years of sampling (1999-2005), suggesting that the population 
TABLE 4. Water column abundances of Calanus finmarchicus (individuals $\mathrm{m}^{-2}$ ) in the ring net tows. BB stands for Bonavista Bay Line; FC, for Flemish Cap Line; SEGB, for South East Grand Bank Line.

\begin{tabular}{|c|c|c|c|c|c|c|c|c|c|c|c|c|c|c|c|}
\hline $\begin{array}{c}\text { Station } \\
\text { name }\end{array}$ & CI & CII & CIII & CIV & $\mathrm{CV}$ & CVI & Total & $\begin{array}{c}\text { Station } \\
\text { name }\end{array}$ & CI & CII & CIII & CIV & $\mathrm{CV}$ & CVI & Total \\
\hline$\overline{\text { BB-01 }}$ & 580 & 1449 & 580 & 1159 & 10577 & 724 & 15069 & $\overline{\text { SEGB-10 }}$ & 9 & 27 & 9 & 14 & 9 & 5 & 72 \\
\hline BB-03 & - & 290 & 290 & 2318 & 15069 & 1739 & 19706 & SEGB-11 & - & - & - & 3767 & 8694 & 145 & 12606 \\
\hline BB-04 & - & - & - & 3478 & 26081 & 1739 & 31298 & SEGB-12 & - & - & 9 & 290 & 380 & 18 & 697 \\
\hline BB-05 & - & - & 290 & 2898 & 17967 & 1159 & 22314 & SEGB-13 & 72 & 299 & 245 & 63 & 9 & - & 688 \\
\hline BB-06 & - & - & 2029 & 4926 & 7824 & 1739 & 16518 & SEGB-15 & - & - & 290 & 1449 & 16808 & 1159 & 19706 \\
\hline BB-07 & - & - & 580 & 1159 & 35355 & 2318 & 39412 & SEGB-16 & 72 & - & 181 & 4274 & 21481 & 1413 & 27422 \\
\hline BB-08 & 290 & 580 & - & 2898 & 15649 & 1739 & 21155 & SEGB-17 & 18 & - & - & 4347 & 18021 & 398 & 22785 \\
\hline BB-09 & - & - & - & 2608 & 15359 & 1449 & 19416 & SEGB-19 & - & - & - & 1739 & 10867 & 145 & 12751 \\
\hline BB-10 & - & - & - & 2318 & 22024 & 3478 & 27820 & GBL2-1 & 904 & 3390 & 9492 & 7006 & 6102 & 452 & 27346 \\
\hline BB-11 & 54 & 54 & 54 & 344 & 8458 & 616 & 9581 & GBL2-2 & 170 & 1130 & 1978 & 1921 & 2656 & 113 & 7967 \\
\hline BB-12 & 36 & 36 & 63 & 213 & 16844 & 1281 & 18474 & GBL1-2 & - & 509 & 452 & 1243 & 2995 & 283 & 5481 \\
\hline BB-13 & - & - & 145 & - & 9708 & 1159 & 11012 & GBL1-2.5 & - & 57 & 452 & 2204 & 6554 & 396 & 9831 \\
\hline BB-14 & 1159 & 398 & 1032 & 1544 & 19321 & 883 & 24338 & SPB5A & 45 & 158 & 158 & 136 & 249 & 23 & 768 \\
\hline BB-15 & - & - & - & 1304 & 11012 & - & 12316 & SPB6 & - & 226 & 565 & 1243 & 14238 & 1017 & 17741 \\
\hline FC-01 & - & 145 & 435 & 724 & 8404 & 1739 & 11447 & CSL1 & 129 & 345 & 1638 & 3880 & 862 & - & 6855 \\
\hline FC-02 & - & 290 & 435 & 869 & 9418 & 435 & 11447 & CSL2 & - & 302 & 2113 & 9054 & 35010 & 604 & 47083 \\
\hline FC-03 & - & - & 290 & 1159 & 21734 & 1449 & 24632 & CSL3 & - & 1191 & 2383 & 10722 & 48251 & 596 & 63143 \\
\hline FC-04 & - & 290 & - & 3478 & 24053 & 1159 & 28979 & CSL4 & - & 596 & 2978 & 17275 & 48846 & 596 & 70291 \\
\hline FC-05 & 145 & 724 & 724 & 724 & 11881 & 435 & 14635 & CSL5 & 362 & 543 & 362 & 4346 & 12676 & 543 & 18833 \\
\hline FC-06 & - & 3478 & 2318 & 16228 & 83460 & 3478 & 108962 & CSL6 & 453 & 226 & 679 & 7244 & 19920 & 679 & 29200 \\
\hline FC-07 & - & 109 & 181 & 580 & 1775 & 254 & 2898 & LL1 & 113 & 792 & 1471 & 2490 & 2660 & 57 & 7583 \\
\hline FC-09 & 688 & 1051 & 761 & 326 & 36 & - & 2862 & LL2 & - & 176 & 654 & 1258 & 2289 & 151 & 4527 \\
\hline FC-10 & 27 & 217 & 154 & 235 & 91 & - & 724 & LL3 & - & 121 & 362 & 2051 & 4101 & 80 & 6714 \\
\hline FC-12 & - & 290 & 290 & 4057 & 22604 & 290 & 27530 & LL4 & - & 262 & 872 & 2224 & 2791 & 87 & 6237 \\
\hline FC-14 & - & - & 580 & 1159 & 44048 & - & 45787 & LL5 & 50 & 352 & 1509 & 4628 & 1710 & - & 8250 \\
\hline FC-15 & 580 & - & 580 & 4637 & 28979 & 5216 & 39991 & LL6 & 70 & 70 & 457 & 773 & 141 & - & 1511 \\
\hline FC-17 & - & - & - & 7417 & 14164 & 489 & 22069 & LL7 & 272 & 362 & 272 & 2173 & 8783 & 272 & 12133 \\
\hline FC-18 & - & 580 & 1159 & 12171 & 31298 & - & 45208 & LL8 & - & - & - & 1250 & 5088 & 302 & 6640 \\
\hline $\begin{array}{l}\text { FC-20 } \\
\text { FC-21 }\end{array}$ & - & - & 290 & $\begin{array}{l}1449 \\
2898\end{array}$ & $\begin{array}{l}22604 \\
21445\end{array}$ & $\begin{array}{r}- \\
580\end{array}$ & $\begin{array}{l}24343 \\
25212\end{array}$ & HL1 & 247 & 741 & 1646 & 1975 & 7243 & 823 & 12676 \\
\hline $\begin{array}{l}F C-21 \\
F C-24\end{array}$ & 2318 & $\begin{array}{l}- \\
-\end{array}$ & $\begin{array}{r}290 \\
1159\end{array}$ & $\begin{array}{l}898 \\
580\end{array}$ & $\begin{array}{l}21445 \\
49265\end{array}$ & 1739 & 55060 & HL2 & 113 & 214 & 1023 & 3810 & 11511 & 1237 & 17908 \\
\hline FC-26 & 1159 & - & - & - & 58538 & 1739 & 61436 & HL3 & - & - & - & 2716 & 16411 & 2377 & 21504 \\
\hline FC-29 & - & - & - & 1739 & 53901 & 580 & 56220 & HL4 & - & - & - & 550 & 550 & 157 & 1258 \\
\hline FC-31 & - & - & - & 4637 & 110121 & - & 114758 & HL5 & - & 23 & - & 23 & 158 & - & 204 \\
\hline FC-33 & - & - & - & 8694 & 40571 & 580 & 49844 & HL6 & 30 & - & - & 392 & 3803 & 151 & 4376 \\
\hline FC-35 & - & - & - & 11012 & 35934 & 1159 & 48105 & HL7 & - & - & - & 373 & 5699 & 320 & 6391 \\
\hline SEGB-01 & - & - & 36 & 109 & 1286 & 109 & 1540 & BBL1 & 198 & 283 & 594 & 1811 & 1528 & 283 & 4697 \\
\hline SEGB-03 & 290 & - & 869 & 4347 & 17098 & 1449 & 24053 & BBL2 & - & 91 & 181 & 1268 & 14034 & 453 & 16026 \\
\hline SEGB-05 & - & - & 290 & 3478 & 15069 & 4057 & 22894 & BBL3 & 328 & 2460 & 4101 & 15091 & 8365 & - & 30345 \\
\hline SEGB-06 & 72 & 290 & 1739 & 2536 & 1014 & 145 & 5796 & BBL4 & 24447 & 46177 & 37123 & 10865 & 4527 & 4527 & 127666 \\
\hline SEGB-07 & 9 & 63 & 104 & 136 & 36 & - & 349 & BBL5 & 91 & 68 & 23 & - & 23 & - & 204 \\
\hline SEGB-08 & 5 & 68 & 136 & 131 & 18 & 5 & 362 & BBL6 & 1132 & 679 & 113 & 1019 & 16072 & 453 & 19467 \\
\hline SEGB-09 & 14 & 41 & 54 & 23 & 9 & - & 140 & BBL7 & 792 & - & - & 453 & 17203 & 453 & 18901 \\
\hline
\end{tabular}

as a whole is only inactive for a rather short period of the year (Pepin et al., MS 2006). Numbers of young stages found in the CSR on autumn AZMP cruises are variable (500-30 $000 \mathrm{~m}^{-2}$, 1998-2005, E. Head, unpublished data), suggesting that there the production season sometimes extends until October. Female $C$. finmarchicus are actively laying eggs in the CSR in April (Campbell and Head, 2000), suggesting that here too the period of dormancy is sometimes short. Durbin et al. (1997) found late autumn-early winter recruitment of $C$. finmarchicus on Georges Bank, but concluded it was due to early arousal from overwintering, rather than prolonged spring/summer production. It is unclear whether our observations on the WSS represent production by individuals that awoke early or by a portion of the population that never entered dormancy. A detailed discussion of the variations in seasonal cycles of $C$. finmarchicus in different regions of the NW Atlantic and how they vary 
from year to year is beyond the scope of this paper, but it is clear that the persistence of $C$. finmarchicus on the Newfoundland Shelf into the autumn and winter, which occurs every year, will influence its distribution in the slope waters downstream. Advection from the shelf can be of late stages (e.g. at the GBL or SPB lines) or young stages, the latter being produced when near-surface, perhaps semi-dormant, late stage $C$. finmarchicus respond to autumn/winter phytoplankton blooms, or a portion of the population may rely more heavily on omnivory during periods of limited primary production.

\section{Inferring inter-regional connectivity from vertical distributions of $\mathrm{CV}$, hydrography and circulation}

For the purposes of this discussion, we will assume that we have an effectively synoptic determination of the vertical distribution of CV C. finmarchicus and hydrography throughout the sampling region. This is a reasonable assumption because adjacent areas sampled at different times showed limited variability (e.g. Scotian Shelf sampled in October and December). The Labrador and Newfoundland slope waters had very similar TS properties below $200 \mathrm{~m}$, which is where most of the CV C. finmarchicus were found (Figs. 7-9). The more inshore stations (e.g. AR7W-08, BB-11, BB-12) showed a greater influence of relatively cool, fresh shelf water at the surface than stations farther offshore (AR7W-10, BB-14) and concentrations of CVs were higher closer to the shelf, suggesting that the shelf could be a source to the slope waters (Figs. 8 and 9, Table 3). Nevertheless, surface concentrations were low and the number of late stage $C$. finmarchicus on the shelf on the BB line was low in November (Fig. 13), so that at this time the main flow of CVs would have been along the slope and not from the shelf to the offshore.

The TS properties below $300 \mathrm{~m}$ in Flemish Pass and off the SE Grand Bank were similar to those farther north on the BB and AR7W lines (Figs. 7-9), but off the SE Grand Bank (SEGB16) there was a cool fresh layer (ca 100-300 m), with TS properties characteristic of the shallow Labrador Slope water that can sometimes penetrate along the slope to the Scotian Shelf (e.g. Greene et al., 2003). This layer was not seen farther upstream because the sampling stations were too far offshore, but it was seen on the SW Grand Bank line (GBL2-3) in December 2003 (Fig. 10), although not farther downstream at the GBL1 line. It was unimportant in the transport of CV C. finmarchicus, which were not abundant in this layer. The TS properties and vertical distribution of CVs were both consistent with transport of overwintering C. finmarchicus from the Newfoundland slope waters to the SE Grand Bank and around the Tail of the Grand
Bank to the GB2 line. Downstream at the GBL1 line, however, there were relatively high levels of CVs in the near surface layers, which were probably derived from the adjacent shallower waters (Fig. 5, Tables 2 and 4). According to a particle tracking study (Luo et al., 2006), these shallow shelf-edge individuals could have been transported here from the outer shelf on the Flemish Cap line and western Flemish Pass, where concentrations were quite high (Fig. 13, Table 4). Individuals arriving in the surface layers of the slope waters probably migrate down as they leave the shelf, so that any flow of organisms from the GBL2 stations at depth is likely to be augmented by the shelf contribution at GBL1.

It is possible that there is input to the offshore SPB stations from upstream at GBL1 (cf. Figs. 10-12). At station SPB08, however, there were large numbers of CVs in the surface layer, in association with a subsurface layer of very cold fresh water that extended to ca $200 \mathrm{~m}$ (Fig. 10) that was most likely derived from Haddock Channel, which runs north-south off the shelf to the east of SPB. The particle tracking study of Luo et al. (2006) suggests that the likely source to Haddock Channel is the inshore branch of the Labrador Current, i.e. the western end of the Flemish Cap line. This latter area had high CV abundance levels (Fig. 13, Table 4) and was the likely source to SPB08. Farther offshore at SPB10, at the $2900 \mathrm{~m}$ isobath, there was little sign of this surface population. West of SPB the flow along the slope diverges with some entering the Laurentian Channel and some continuing southwest. It is possible that this was the source of the very cold water seen at stations in Laurentian Channel offshore from Cabot Strait (LCN and LCL4) in autumn 2003 (Fig. 12), although at both stations the Calanus populations probably derive mainly from the CSR. This is concluded not only because $C$. finmarchicus were more abundant at these stations relative to SPB08 in winter and SPB09 in autumn (Figs. 10 and 11, Table 3), but more obviously because Calanus hyperboreus, which are abundant in the Gulf of St. Lawrence, were as numerous as $C$. finmarchicus at all of the CSR stations, including these two, whereas they were ten times less abundant than $C$. finmarchicus at stations off SPB (E. Head, unpublished data).

Calanus finmarichicus found off the Eastern Scotian Shelf (LL line) probably represent a mixture of animals coming along the slope from southern Newfoundland, and from the Gulf of St. Lawrence through Cabot Strait. Stage CV C. finmarchicus at stations in the CSR in autumn 2003 were most concentrated above $300 \mathrm{~m}$ (Fig. 12), which was consistent with this being a source to the 0-400 $\mathrm{m}$ layer at LL7 off the ESS (Fig. 11). The TS properties are also consistent with this view, as was 
the observation that $C$. hyperboreus were nearly as abundant as $C$. finmarchicus. The relatively low numbers of CV C. finmarchicus below $400 \mathrm{~m}$ at LL7 could, however, have been derived from the slope water current, i.e. from off SPB. At the $2000 \mathrm{~m}$ isobath (LL8), there was no sign of the shallow CSR population, six times fewer $C$. hyperboreus than $C$. finmarchicus and the CVs were at the same depth as those at SPB09 (Fig. 11). Yet farther offshore, at LL9, the CVs were shallow again, and $C$. hyperboreus were three times less abundant than C. finmarchicus (Fig. 12). To the west of the LL line, at the DEC17 stations, CV C. finmarchicus were again relatively shallow, consistent with their being derived from the CSR, but $C$. hyperboreus were 4-7 times less abundant than $C$. finmarchicus. Farther downstream at SIB06, C. hyperboreus were 10 times less abundant than C. finmarchicus and the CVs were at the same depth as at SPB09 (Fig. 11). Off the central and western Scotian Shelf CV C. finmarchicus were generally below $400 \mathrm{~m}$ (Figs. 10-12). At HL6 in winter C. hyperboreus were half as abundant as $C$. finmarchicus, and on and west of the central Scotian Shelf they were 5-20 times less abundant.

The TS properties of the slope waters in which the CVs were found west of SIB06 were generally a little warmer than those between the GBL2 and DEC-17 lines, due to a greater contribution of warm water from the south, and this is consistent with the relative levels of the two Calanus species and the diminishing influence of the outflow from the CSR. This interpretation is also consistent with the accepted circulation pattern (Fig. 1), which indicates flow is generally from northeast to southwest. Reversals in direction of this flow have been observed in records collected by current meters deployed off the central Scotian Shelf, however. These reversals are thought to be associated with the presence of meso-scale anti-cyclonic eddies, which can impinge on the shelf-break. In fact, the direction of flow between July and November 2003 near HL6 was apparently from southwest to northeast (J.W. Loder, unpublished data) and interestingly, high abundances of $C$. finmarchicus off the WSS decreased (RL5, RL6, BBL7), while the low abundance of $C$. finmarchicus at HL7 increased, between October and December (Table 3). Whether the change in flow direction was responsible for the changes in abundance cannot be proven, but the fact that reversals can occur suggests that $C$. finmarchicus can sometimes be transported from southwest to northeast.

A high degree of inter-regional connectivity was implied for $C$. finmarchicus populations in the NW Atlantic by the coupled physical-biological model of
Speirs et al. (2006), such that inoculating a small area of the sub-polar gyre (centred at $\sim 55^{\circ} \mathrm{N} 50^{\circ} \mathrm{W}$ ) with C. finmarchicus led to dispersal of individuals throughout the sub-polar and Slope Water gyres over six years. Our observations do not contradict this result, but they suggest that the data and assumptions used in the model may have been inadequate. Firstly, it was assumed that C. finmarchicus populations are dormant in autumn and winter, which is apparently not the case everywhere in the NW Atlantic, and which could certainly influence model results in some areas. Secondly, no data on overwintering depth distributions for $C$. finmarchicus in the slope waters off the Newfoundland and Scotian shelves were used, which could affect the modelled degrees of retention within the sub-polar or Slope Water gyres. It will be interesting to see how this and any other models respond to these new data inputs.

\section{Variations in vertical distribution of overwintering C. finmarchicus in different regions: can they be ex- plained?}

In our observations, overwintering $C$. finmarchicus were found in the slope waters over a range of TS conditions. The highest concentrations of overwintering $\mathrm{CV}$ C. finmarchicus $\left(>100 \mathrm{~m}^{-3}\right)$ were found in waters of low ( $\sim 3^{\circ} \mathrm{C}$, Newfoundland slope), intermediate $\left(\sim 5^{\circ} \mathrm{C}\right.$, Cabot Strait) and high $\left(\sim 9^{\circ} \mathrm{C}\right.$, Emerald Basin) temperatures at depths of 400-600, 200-300 and 100-260 m, respectively (Figs. 7-12). High concentrations were also associated with temperatures of $<2^{\circ} \mathrm{C}(100-200 \mathrm{~m})$ in Cabot Strait, although when sampling depth intervals were chosen to isolate the cold intermediate layer in October 2006, it was found to have 5-10 times fewer C. finmarchicus than the layers above and beneath it (E. Head, unpublished data), so that the occurrence of high overwintering concentrations at very low temperatures in 2003 was probably apparent, rather than real. Whether the populations overwintering at relatively high temperatures suffer high mortality because of high metabolic costs or losses to predators is not clear, but populations in both Emerald Basin and Cabot Strait would likely be subject to heavy predation by fish and invertebrates (see below).

Several suggestions have been made as to why C. finmarchicus overwinter at particular depths in different areas, but none of them can readily explain the differences seen throughout our NW Atlantic sampling area. One suggestion is that $C$. finmarchicus migrate to a depth with a fixed daytime light intensity (Miller et al., 1991). In such a scenario overwintering individuals should be deepest at the most southerly latitudes. In our study, however, where bottom depths were not limiting, there was no relationship between overwintering depth 
and latitude; the deepest overwintering population was in fact at one of the most northerly stations, in the Greenland Slope waters at $>60^{\circ} \mathrm{N}$ (AR7W-24).

Another suggestion is that overwintering depths are selected to avoid predators (Kaartvedt, 1996). Dale et al. (1999) reported that in the Norwegian Sea C. finmarchicus were distributed deepest in areas where Atlantic water was dominant and shallower in Arctic waters and they attributed this to differences in the abundance of mesopelagic fish in the water masses. In the Labrador Sea, the distribution pattern was somewhat similar to that in the Norwegian Sea, in that individuals were deepest in the waters having the highest Atlantic water contribution (i.e. the Greenland Slope) and shallower farther west, where the Arctic water influence was greater (as indicated by the lower salinities). On the other hand, Dale et al. (1999) sampled only to $1000 \mathrm{~m}$, which seems to have included the bulk of the $C$. finmarchicus population, while in the Greenland Slope waters the depth distribution was substantially deeper, as was also the case in the Irminger Basin (Gislason and Astthorsson, 2000). The dominant mesopelagic fish species, the myctophid Benthosema glaciale, is confined to the upper $1000 \mathrm{~m}$ in the northern Labrador Sea (Sameoto, 1989), so that C. finmarchicus in the Greenland Slope waters seem to be migrating to excessive depths, if they are trying to avoid mesopelagic fish predation. Sameoto (1989) also observed that the daytime peak in the vertical distribution of the $B$. glaciale in the northern Labrador Sea/Baffin Bay in August 1983 was at 400-600 m, coincident with one of the highest concentrations $\left(\sim 100 \mathrm{~m}^{-3}\right)$ of overwintering $C$. finmarchicus seen in this study, in the Newfoundland slope waters (BB-12, Fig. 9). Recent observations in the western Labrador Sea have shown that the mean depth at which $C$. finmarichus overwinters corresponds closely to the depth of the deep scattering layer determined in June-September 2006, which consisted principally of $B$. glaciale (P. Pepin, unpublished data) and that late stage $C$. finmarchicus and $C$. glacialis were in fact numerically the most important prey item found in B. glaciale stomachs (P. Pepin, unpublished data). Mesopelagic fish are not the only potential predators of $C$. finmarchicus overwintering in the Labrador Sea, however. Sameoto (1987) reported that chaetognaths are major predators on copepods in the northern Labrador Sea and Baffin Bay and that in summer substantial levels of chaetognath biomass extend to depths of $1000 \mathrm{~m}$. In addition, we have observed large decapods in deep tows in the Labrador Sea, at concentrations such that their biomass sometimes exceeds that of the copepods in some depth intervals (E. Head, personal observation). Farther south, in the relatively shallow waters of Cabot
Strait, overwintering $C$. finmarchicus were most abundant in the 200-300 m interval and not very abundant in the near-bottom layers. This might relate to predator avoidance, since some near-bottom living fish species (e.g. redfish) are quite abundant there (data from the Marine Fish Division Virtual Data Centre (MFDVDC) held at the Bedford Institute of Oceanography). In Emerald Basin silver hake are abundant (MFDVDC) and C. finmarchicus concentrations are lower near the bottom than at slightly shallower depths (Sameoto et al., 1994). In both areas the carnivorous euphausiid Meganyctiphanes norvegica is also abundant in the near-bottom layer during the daytime (Sameoto et al., 1994; E. Head, personal observation). Overall, we cannot say whether predator avoidance is a major determinant of $C$. finmarchicus overwintering depth distribution.

Heath and Jónasdóttir (1999) investigated the vertical distribution of $C$. finmarchicus in the Faroe-Shetland channel and found that the overwintering population was associated with the Arctic water near the bottom of the channel, and that these individuals had a high fat content relative to those overwintering in nearby waters. Visser and Jónasdóttir (1999) showed in a modelling study that the fat body inside overwintering $C$. finmarchicus varies in density with pressure (i.e. depth) and temperature, such as to change the overall density of the animal, so that individuals with different fat content may be neutrally buoyant at different depths, with salinity also having an influence via its effect on water density. Assuming that overwintering $C$. finmarchicus are neutrally buoyant, Heath et al. (2004) developed this idea to calculate the implied fat content for $C$. finmarchicus overwintering in several regions of the North Atlantic: this analysis included the Labrador Sea data presented here. When we calculated the implied fat content of overwintering C. finmarchicus in the Labrador Sea, we found that below $200 \mathrm{~m}$ it was, in fact, essentially constant with depth and over all stations $( \pm 2 \%)$, because fat density is more dependent on temperature than on pressure, and temperatures varied very little, and because salinities were also relatively constant (Fig. 7). Thus, in the Labrador Sea differences in fat content and density are not likely to be responsible for variations in the vertical distribution of overwintering C. finmarchicus.

Visser and Jónasdóttir (1999) suggested that $C$. finmarchicus should become positively buoyant as they start to leave their over wintering depths to return to the surface, which would enable them to conserve energy reserves during their ascent. In several of the areas where we sampled, however, $C$. finmarchicus leaving their overwintering depths will encounter water that is both cooler 
and fresher as they ascend so that their fat bodies will become denser and they will become negatively buoyant and will have to swim up actively. Backhaus et al. (2003) suggested that overwintering copepods might save energy during ascent by being brought to the surface during deep water column convection in late winter. For this to be effective he suggested that overwintering should be at depths near to, but below, the depth of convection (J. O. Backhaus, Pers. Comm.). Irigoien (2004) also suggested that overwintering should occur below the depth of convection. He hypothesised that overwintering depth selection is a heritable trait that is related to lipid content and its effect on buoyancy and that individuals that do not overwinter below the depth of winter convection will not survive and will be selected against genetically. The behaviour of the Labrador Sea $C$. finmarchicus population does not support these hypotheses: the western/central Labrador Sea is one of the world's deep convection areas with convection depths generally reaching $1000 \mathrm{~m}$, but in central and western regions $C$. finmarchicus overwinter at depths of $<1000 \mathrm{~m}$, and large numbers of overwintered individuals apparently survive through to the spring (Head et al., 2003).

\section{Conclusions}

Our observations of the vertical distribution and abundance of $C$. finmarchicus and of hydrography in the slope waters of the NW Atlantic are consistent with the accepted pattern of circulation and connectivity of overwintering C. finmarchicus populations between adjacent regions. Transport around the Tail of the Grand Bank seems to be limited, with most of the southwesterly flow along the SE Grand Bank being deflected to join the northeasterly flowing North Atlantic Current, and there is flow into and out from the Laurentian Channel, so that the system is clearly not a simple continuum. One novel and confounding finding is that $C$. finmarchicus on the Newfoundland Shelf, in the Cabot Strait region and in some areas of the Scotian Shelf may have prolonged production seasons, so that the slope water populations can receive important inputs from these sources in autumn and winter. These probable effects of local secondary production are unlikely to have been included in current coupled transport/population dynamics models. As well, we note that there are periodic reversals of the southwesterly flow along the Scotian Shelf, which could cause northwesterly transport of $C$. finmarchicus from western to central regions, contrary to the expected direction of flow. Finally, our results suggest that the vertical distribution of overwintering $C$. finmarchicus is not constrained in extent by temperature or salinity in the NW Atlantic and we have found no one explanation that can account for the broad range of overwintering depths observed in this study.

\section{References}

BACKHAUS, J. O., E. N. HEGSETH, H. WEHDE, X. IRIGOIEN, K. HATTEN, and LOGEMANN, K. 2003. Convection and primary production in winter. Mar. Ecol. Prog. Ser., 251: 1-14. doi:10.3354/meps251001

CAMPBELL, R.W., and E. J. H. HEAD. 2000. Egg production rates of Calanus finmarchicus in the western North Atlantic: effect of gonad maturity, female size, chlorophyll concentration, and temperature. Can. J. Fish. Aquat. Sci., 57: 518-529. doi:10.1139/cjfas-57-3-518

CAMPBELL, R. G., M. M. WAGNER, G. J. TEEGARDEN, C. A. BOUDREAU, and E. G. DURBIN. 2001. Growth and development rates of the copepod Calanus finmarchicus reared in the laboratory. Mar. Ecol. Prog. Ser., 221: 161-183. doi:10.3354/meps221161

CONOVER, R. J. 1988. Comparative life histories in the genera Calanus and Neocalanus in high latitudes of the northern hemisphere. Hydrobiologia, 167/168: 127-142. doi:10.1007/BF00026299

DALE, T., E. BAGOIEN, W. MELLE, and S. KAARTVEDT. 1999. Can predator avoidance explain varying overwintering depth of Calanus in different oceanic water masses? Mar. Ecol. Prog. Ser., 179: 113-121. doi:10.3354/ meps179113

DURBIN, E.G., J. A. RUNGE, R. G. CAMPBELL, P. R. GARRAHAN, M. C. CASAS, and S. PLOURDE. 1997. Late autumn-early winter recruitment of Calanus finmarchicus on Georges Bank. Mar. Ecol. Prog. Ser., 151: 103-114. doi:10.3354/meps151103

GISLASON, A., and O.S. ASTTHORSSON. 2000. Winter distribution, ontogenetic migration, and rates of egg production of Calanus finmarchicus southwest of Iceland. ICES J. Mar. Sci., 57: 1727-1739. doi:10.1006/jmsc.2000.0951

GREENE, C. H., A. J. PERSHING, A. CONVERSI, B. PLANQUE, C. HANNAH, D. SAMEOTO, E. HEAD, P. C. SMITH, P. C. REID, J. JOSSI, D. MOUNTAIN, M. C. BENFIELD, P. C. WIEBE, E. DURBIN. 2003. Trans-Atlantic responses of Calanus finmarchicus to basin-scale forcing associated with the North Atlantic oscillation. Prog. Oceanogr., 58, 301-312.

HALVORSEN, E., K. S. TANDE, A. EDVARDSEN, D. SLAGSTAD, and O. P. PEDERSEN. 2003. Habitat selection of overwintering Calanus finmarchicus in the NW Norwegian Sea and shelf waters off Northern Norway in 2000-02. Fish. Oceanogr., 12: 339-351. doi:10.1046/ j.1365-2419.2003.00255.x

HEAD, E. J. H., L. R. HARRIS, and R. W. CAMPBELL. 2000. Investigations on the ecolgy of Calanus spp. in the Labrador Sea. I., relationship between the phytoplankton bloom and reproduction and development of Calanus finmarchicus in spring. Mar. Ecol. Prog. Ser., 193: 53-73. doi:10.3354/meps193053 
HEAD, E. J. H., L. R. HARRIS, and B. PETRIE. 1999. Distribution of Calanus spp. on and around the Nova Scotia shelf in April - evidence for an offshore source of Calanus finmarchicus to the mid- and western regions. Can. J. Fish. Aquat. Sci., 56: 2463-2476. doi:10.1139/cjfas-5612-2463

HEAD, E. J. H., L. R. HARRIS, and I. YASHAYAEV. 2003. Distributions of Calanus spp. and other mesozooplankton in the Labrador Sea in relation to hydrography in spring and early summer (1995-2000). Prog. Oceanogr., 59: 1-30. doi:10.1016/S0079-6611(03)00111-3

HEAD, E. J. H., and D. D. SAMEOTO. 2007. Interdecadal variability in zooplankton and phytoplankton abundance on the Newfoundland and Scotian shelves. Deep-Sea Res. II, 54: 2686-2701.

HEATH, M. R., P. R. BOYLE, A. GISLASON, W. S. C. GURNEY, S. J. HAY, E. J. H. HEAD, S. HOLMES, A. INGVARSDÓTTIR, S. H. JÓNASDÓTTIR, P. LINDEQUE, R. T. POLLARD, J. RASMUSSEN, K. RICHARDS, K. RICHARDSON, G. SMERDON, and D. SPIERS. 2004. Comparative ecology of overwintering Calanus finmarchicus in the northern North Atlantic and implications for life cycle patterns. ICES J. Mar. Sci., 61: 698-708. doi:10.1016/j.icesjms.2004.03.013

HEATH, M. R., J. G. FRASER, A. GISLASON, S. J. HAY, S. H. JÓNASDÓTTIR, and K. RICHARDSON. 2000. Winter distribution of Calanus finmarchicus in the Northeast Atlantic. ICES J. Mar. Sci., 57: 1628-1635. doi:10.1006/ jmsc. 2000.0978

HEATH, M.R., and S. H. JÓNASDÓTTIR. 1999. Distribution and abundance of overwintering Calanus finmarchicus in the Faroe-Shetland Channel. Fish. Oceanogr., 8 (Suppl. 1): 40-60. doi:10.1046/j.1365-2419.1999.00012.x

HOLM-HANSEN, O., C. J. LORENZEN, R. W. HOLMES, and J. D. H. STRICKLAND. 1965. Fluorometric determination of chlorophyll. J. Cons. Int. Expl. Mer., 30: $3-15$.

IRIGOIEN, X. 2004. Some ideas about the role of lipids in the life cycle of Calanus finmarchicus. J. Plankton Res., 26: 259-263. doi:10.1093/plankt/fbh030

KAARTVEDT, S. 1996. Habitat preference during overwintering and timing of seasonal vertical migration of Calanus finmarchicus. Ophelia, 44: 145-156.

LODER, J. W., B. PETRIE, and G. GAWARKIEWICZ. 1998. The coastal ocean off northeastern North America: a large-scale view. In: The Sea, Vol 11: The global coastal ocean: regional studies and syntheses. A. R. Robinson and K. H. Brink (eds.). Wiley, New York, p. 105-133.

LUO, Y., M. D. PRATER, E. G. DURBIN, and L. M. ROTHSTEIN. 2006. Changes in the Northwest Atlantic circulation for the 1992-1995 high NAO period from a numerical model. Con. Shelf. Res., 26: 1617-1635. doi:10.1016/ j.csr.2006.05.006

MCLAREN, I.A., E. HEAD, and D. D. SAMEOTO. 2001. Life cycles and seasonal distributions of Calanus finmarchicus on the central Scotian Shelf. Can. J. Fish. Aquat. Sci., 58: 659-670. doi:10.1139/cjfas-58-4-659

MILLER, C. B., T. J. COWLES, P. H. WIEBE, N. J. COPLEY, and H. GRIGG. 1991. Phenology in Calanus finmarchicus; hypothesis about control mechanisms. Mar. Ecol. Prog. Ser., 72: 79-91. doi:10.3354/meps072079

NIEHOFF, B., U. KLENKE, H.-J. HIRCHE, X. IRIGOIEN, R. HEAD, and R. HARRIS. 1999. A high frequency time series at Weathership M, Norwegian Sea, during the 1997 spring bloom: the reproductive biology of Calanus finmarchicus. Mar. Ecol. Prog. Ser, 176: 81-91. doi:10.3354/ meps176081

PEPIN, P., G. L. MAILLET, S. FRASER, and D. LANE. MS 2006. Biological and chemical oceanographic conditions on the Newfoundland Shelf during 2005. Canadian Science Advisory Secretariat, Research Document, 2003/063, $39 \mathrm{p}$.

PLOURDE, S., and J.A. RUNGE. 1993. Reproduction of the planktonic copepod Calanus finmarchicus in the Lower St. Lawrence Estuary: relation to the cycle of phytoplankton production and evidence for a Calanus pump. Mar. Ecol. Prog. Ser., 122: 217-227.

SAMEOTO, D. D. 1987. Vertical distribution and ecological significance of chaetognaths in the Arctic environment of Baffin Bay. Polar Biol., 7: 317-328. doi:10.1007/ BF00293222

SAMEOTO, D. 1989. Feeding ecology of the lantern fish Benthosema glaciale in a subarctic region. Polar Biol., 9: 169-178. doi:10.1007/BF00297172

SAMEOTO, D. D., and A. W. HERMAN. 1990. Life cycles and distribution of Calanus finmarchicus in deep basins on the Nova Scotia shelf and seasonal changes in Calanus spp. Mar. Ecol. Prog. Ser., 66: 225-237. doi:10.3354/ meps066225

SAMEOTO, D. D., J. NEILSEN, and D. WALDRON. 1994. Zooplankton prey selection by juvenile fish in Nova Scotian Shelf basins. J. Plankton Res., 16: 1003-1019. doi:10.1093/plankt/16.8.1003

SPEIRS, D. C., W. S. C. GURNEY, M. R. HEATH, W. HORBETT, S. N. WOOD, and B. A. DE CUEVAS. 2006. Ocean-scale modelling of the distribution, abundance, and seasonal dynamics of the copepod Calanus finmarchicus. Mar. Ecol. Prog. Ser., 313: 173-192. doi:10.3354/ meps313173

THERRIAULT, J. C., B. PETRIE, P. PEPIN, J. GAGNON, D. GREGORY, J. HELBIG, A. HERMAN, D. LEFAIVRE, M. MITCHELL, B. PELCHAT, J. RUNGE, and D. SAMEOTO. 1998. Proposal for a Northwest Atlantic Zonal Monitoring Program. Can. Tech. Rep. Hydrogr. Ocean Sci., No. 194, 64 p.

VISSER, A. W., AND S. H. JÓNASDÓTTIR. 1999. Lipids, buoyancy and the seasonal vertical migration of Calanus finmarchicus. Fish. Oceanogr., 8 (Suppl. 1): 100-106. doi:10.1046/j.1365-2419.1999.00001.x

WELSHMEYER, N.A. 1994. Fluorometric analysis of chlorophyll $a$ in the presence of chlorophyll $b$ and pheopigments. Limnol. Oceangr., 39: 1985-1992.

WIEBE, P. H. 2001. A grand challenge - Synthesis of North Atlantic GLOBEC data sets through basin-wide studies of zooplankton involving observations and modeling. In: (2001) The North West Atlantic Ecosystem - A basin 
scale approach. E. Head, P. Pepin, and J. Runge. (eds.). CSAS Proceedings Ser. 2001/23.

ZAKARDJIAN, B. A., J. SHENG, J. A. RUNGE, I. MCLAREN, S. PLOURDE, K. R. THOMPSON, and Y. GRATTON. 2003. Effects of temperature and circulation on the population dynamics of Calanus finmarchicus in the Gulf of St. Lawrence and Scotian Shelf: study with a coupled, three-dimensional hydrodynamic, stage-based life history model. J. Geophys. Res. (C Oceans), 108 (C 11), 8016. doi:10.1029/2002JC001410 